\title{
Deriving a light use efficiency model from eddy covariance flux data for predicting daily gross primary production across biomes
}

\author{
Authors: Yuan, Wenping, Shuguang Liu, Guangsheng \\ Zhou, Guoyi Zhou, Larry L. Tieszen, Dennis Baldocchi, \\ Christian Bernhofer, Henry Gholz, Allen H. Goldstein, \\ Michael L. Goulden, David Y. Hollinger, Yueming Hu, \\ Beverly E. Law, Paul C. Stoy, Timo Vesala, and Steven C. \\ Wofsy
}

NOTICE: this is the author's version of a work that was accepted for publication in Agricultural and Forest Meteorology. Changes resulting from the publishing process, such as peer review, editing, corrections, structural formatting, and other quality control mechanisms may not be reflected in this document. Changes may have been made to this work since it was submitted for publication. A definitive version was subsequently published in Agricultural and Forest Meteorology, VOL\# 142, ISSUE\# 3-4, (April 2007), DOI\# 10.1016/j.agrformet.2006.12.001.

Yuan, Wenping, Shuguang Liu, Guangsheng Zhou, Guoyi Zhou, Larry L. Tieszen, Dennis Baldocchi, Christian Bernhofer, Henry Gholz, Allen H. Goldstein, Michael L. Goulden, David Y. Hollinger, Yueming Hu, Beverly E. Law, Paul C. Stoy, Timo Vesala, and Steven C. Wofsy. "Deriving a Light Use Efficiency Model from Eddy Covariance Flux Data for Predicting Daily Gross Primary Production Across Biomes." Agricultural and Forest Meteorology 143, no. 3-4 (April 2007): 189-207. doi:10.1016/j.agrformet.2006.12.001. 


\title{
Deriving a light use efficiency model from eddy covariance flux data for predicting daily gross primary production across biomes
}

\author{
Wenping Yuan ${ }^{\mathrm{a}, \mathrm{b}}$, Shuguang Liu ${ }^{\mathrm{c}, \mathrm{d}, *}$, Guangsheng Zhou ${ }^{\mathrm{a}, * *}$, Guoyi Zhou ${ }^{\mathrm{e}}$, \\ Larry L. Tieszen ${ }^{\mathrm{f}}$, Dennis Baldocchi ${ }^{\mathrm{g}}$, Christian Bernhofer ${ }^{\mathrm{h}}$, Henry Gholz ${ }^{\mathrm{i}}$, \\ Allen H. Goldstein ${ }^{j}$, Michael L. Goulden ${ }^{k}$, David Y. Hollinger ${ }^{1}$, Yueming Hu ${ }^{\mathrm{m}}$, \\ Beverly E. Law ${ }^{\mathrm{n}}$, Paul C. Stoy ${ }^{\mathrm{o}, \mathrm{p}}$, Timo Vesala ${ }^{\mathrm{q}}$, Steven C. Wofsy ${ }^{\mathrm{r}}$ \\ other AmeriFlux collaborators
}

\footnotetext{
${ }^{a}$ Laboratory of Quantitative Vegetation Ecology, Institute of Botany, The Chinese Academy of Sciences (CAS), 20 Nanxincun Xiangshan, Haidian District, Beijing 100093, China

${ }^{\mathrm{b}}$ Graduate School of the CAS, Beijing 100039, China

${ }^{\mathrm{c}}$ SAIC, U.S. Geological Survey Center for Earth Resources Observation and Science, Sioux Falls, SD 57198, USA

${ }^{\mathrm{d}}$ Geographic Information Science Center of Excellence, South Dakota State University, Brookings, SD 57007, USA ${ }^{\mathrm{e}}$ South China Botanic Garden, CAS, Guangzhou, China

${ }^{\mathrm{f}}$ U.S. Geological Survey Center for Earth Resources Observation and Science, Sioux Falls, SD 57198, USA

${ }^{\mathrm{g}}$ Ecosystem Sciences Division, Department of Environmental Science, Policy and Management, 137 Mulford Hall, University of California, Berkeley, CA 94720, USA

${ }^{\mathrm{h}}$ Technische Universitaet Dresden, 01062 Dresden, Germany

${ }^{\mathrm{i}}$ Long Term Ecological Research Program, Division of Environmental Biology, National Science Foundation, 4201 Wilson Boulevard, Arlington, VA 22230, USA

${ }^{\mathrm{j}}$ Department of Environmental Science, Policy \& Management, University of California at Berkeley, 137 Mulford Hall, 3114 Berkeley, CA 94720-3114, USA

${ }^{\mathrm{k}}$ Department of Earth System Science, University of California, Irvine, California 92697-3100, USA

${ }^{1}$ USDA Forest Service NE Research Station, Durham, NH 03824, USA

${ }^{\mathrm{m}}$ South China Agricultural University, Guangzhou 510642, China

${ }^{\mathrm{n}}$ College of Forestry, Oregon State University, Corvallis, OR 97331, USA

${ }^{\circ}$ Nicholas School of the Environment and Earth Sciences, Box 90328, Duke University, Durham, NC 27708, USA

${ }^{\mathrm{p}}$ University Program in Ecology, Duke University, Durham, NC 27708, USA

${ }^{\mathrm{q}}$ Department of Physical Sciences, University of Helsinki, P.O. Box 64, FIN-00014 Helsinki, Finland

${ }^{\mathrm{r}}$ Division of Applied Sciences, Department of Earth and Planetary Sciences, Harvard University, Cambridge, MA, USA

Received 17 July 2006; received in revised form 2 December 2006; accepted 8 December 2006
}

\begin{abstract}
The quantitative simulation of gross primary production (GPP) at various spatial and temporal scales has been a major challenge in quantifying the global carbon cycle. We developed a light use efficiency (LUE) daily GPP model from eddy covariance (EC) measurements. The model, called EC-LUE, is driven by only four variables: normalized difference vegetation index (NDVI), photosynthetically active radiation (PAR), air temperature, and the Bowen ratio of sensible to latent heat flux (used to calculate
\end{abstract}


moisture stress). The EC-LUE model relies on two assumptions: First, that the fraction of absorbed PAR (fPAR) is a linear function of NDVI; Second, that the realized light use efficiency, calculated from a biome-independent invariant potential LUE, is controlled by air temperature or soil moisture, whichever is most limiting. The EC-LUE model was calibrated and validated using 24,349 daily GPP estimates derived from 28 eddy covariance flux towers from the AmeriFlux and EuroFlux networks, covering a variety of forests, grasslands and savannas. The model explained $85 \%$ and $77 \%$ of the observed variations of daily GPP for all the calibration and validation sites, respectively. A comparison with GPP calculated from the Moderate Resolution Imaging Spectroradiometer (MODIS) indicated that the EC-LUE model predicted GPP that better matched tower data across these sites. The realized LUE was predominantly controlled by moisture conditions throughout the growing season, and controlled by temperature only at the beginning and end of the growing season. The EC-LUE model is an alternative approach that makes it possible to map daily GPP over large areas because (1) the potential LUE is invariant across various land cover types and (2) all driving forces of the model can be derived from remote sensing data or existing climate observation networks.

(C) 2007 Elsevier B.V. All rights reserved.

Keywords: Gross primary production; Light use efficiency; Eddy covariance; EC-LUE model; Evaporative fraction; NDVI

\section{Introduction}

Predicting the gross primary productivity (GPP) of terrestrial ecosystems has been a major challenge in quantifying the global carbon cycle (Canadell et al., 2000). Among all the predictive methods, the light use efficiency (LUE) model may have the most potential to adequately address the spatial and temporal dynamics of GPP because of its theoretical basis and practicality (Running et al., 2000). The LUE model is built upon two fundamental assumptions (Running et al., 2004): (1) that ecosystem GPP is directly related to absorbed photosynthetically active radiation (APAR) through LUE, where LUE is defined as the amount of carbon produced per unit of APAR and (2) that realized LUE may be reduced below its theoretical potential value by environmental stresses such as low temperatures or water shortages (Landsberg, 1986). The general form of the LUE model is:

$$
\mathrm{GPP}=\mathrm{fPAR} \times \mathrm{PAR} \times \varepsilon_{\max } \times f
$$

where PAR is the incident photosynthetically active radiation $\left(\mathrm{MJ} \mathrm{m}^{-2}\right.$ ) per time period (e.g., day or month), fPAR is the fraction of PAR absorbed by the vegetation canopy, $\varepsilon_{\max }$ is the potential LUE $\left(\mathrm{g} \mathrm{C} \mathrm{m}^{-2} \mathrm{MJ}^{-1}\right.$ APAR) without environment stress, and $f$ is a scalar varying from 0 to 1 and represents the reduction of potential LUE under limiting environmental conditions, the multiplication of $\varepsilon_{\max }$ and $f$ is realized LUE.

Independently and as a part of integrated ecosystem models, the LUE approach has been used to estimate GPP and net primary production (NPP) at various spatial and temporal scales (Potter et al., 1993; Prince and Goward, 1995; Landsberg and Waring, 1997; Coops et al., 2005; Running et al., 2000; Xiao et al., 2004; Law and Waring, 1994a).
The CASA model (Potter et al., 1993) combines AVHRR satellite data, monthly temperature, precipitation, soil attributes, and a biome-independent potential LUE of $0.389 \mathrm{~g} \mathrm{C} \mathrm{m}^{-2} \mathrm{MJ}^{-1}$ APAR to estimate global terrestrial NPP.

The Global Production Efficiency Model (GLOPEM) (Prince and Goward, 1995) simulates both global GPP and global NPP by retrieving APAR directly from satellite data, along with environmental variables that affect the utilization of APAR.

The 3-PG model (Physiological Principles in Predicting Growth) (Landsberg and Waring, 1997) calculates forest GPP from APAR and LUE, and takes into consideration the effects of freezing temperatures, soil drought, atmospheric vapor pressure deficits, soil fertility, carbon allocation, and stand age. A model output is NPP, where the NPP/GPP ratio is assumed to be fairly constrained (Waring et al., 1998). A spatial version of 3-PG, is based on spatially derived climatology, soil surveys, and remote sensing estimates of fPAR.

MODIS-GPP algorithms (Running et al., 1999, 2000) also rely heavily on the LUE approach, with inputs from MODIS LAI/fPAR (MOD15A2), land cover, and biome-specific climatologic data from NASA's Data Assimilation Office. Light use efficiency $(\varepsilon)$ is calculated from two factors: the biome-specific maximum conversion efficiency $\varepsilon_{\max }$, a multiplier that reduces the conversion efficiency when cold temperatures limit plant function, and a second multiplier that reduces the maximum conversion efficiency when vapor pressure deficit (VPD) is high enough to inhibit photosynthesis. It is assumed that soil water deficit covaries with VPD and that VPD will account for drought stress. The GPP algorithm was tested with flux datasets from a range of biomes (Heinsch et al., 2006).

In the Vegetation Production Model (VPM) (Xiao et al., 2004), the potential LUE is affected by 
temperature, land surface moisture condition and leaf phenology. The model C-Fix (Veroustraete et al., 2002) is driven by temperature, radiation and fPAR.

Although these LUE models have been used to estimate global or regional patterns of GPP or NPP, the LUE values on which they are based need to be calibrated rigorously because they greatly impact the accuracy of the model. The C-Fix model assumes a value of $1.1 \mathrm{~g} \mathrm{C} \mathrm{m}^{-2} \mathrm{MJ}^{-1}$ APAR as the invariant realized LUE value for the calculation of GPP, while other models are based on the concept of potential LUE regulated by environmental conditions (Table 1). GLOPEM calculates the potential light use efficiency for $\mathrm{C}_{3}$ plants (Table 1), while the potential LUE value for $\mathrm{C}_{4}$ plants is fixed at $2.76 \mathrm{~g} \mathrm{C} \mathrm{m}^{-2} \mathrm{MJ}^{-1} \mathrm{APAR}$. The MODIS-GPP algorithm relies on BIOME-BGC to compute the LUE of the MODIS-GPP product based on the standard global 1-km biome classification for Earth Observation Systems. Some LUE models apply a value for universal mean realized LUE taken from the literature sources as model inputs for various ecosystems, but some research suggests that realized LUE is not a universal constant (Russell et al., 1989).

Another important parameter in the LUE model is fPAR. In general, fPAR can be derived from remotely sensed data because of the connection between absorbed solar energy and satellite-derived spectral indices of vegetation (Myneni and Williams, 1994). This connection is usually realized by the implementation of Beer's law that defines light absorption as a factor of leaf area index (Bondeau et al., 1999; Running et al., 2004). A few studies have also shown that fPAR is linearly related to the normalized difference vegetation index (NDVI) across different biomes (Ruimy and Saugier, 1994; Myneni and Williams, 1994; Law and Waring, 1994b). It would be very useful if the linear relationship between fPAR and NDVI could be implemented in the LUE model to address the spatial and temporal variability of GPP.

Eddy covariance (EC) measurements recorded by the increasing number of EC towers offer the best opportunity for estimating GPP and developing LUE models. The concurrent measurements of meteorological variables such as temperature and vapor pressure, as well as water balance variables including evapotranspiration and soil water status, provide unprecedented datasets for investigating the dynamics and driving variables of GPP. The $\mathrm{CO}_{2} \mathrm{EC}$ flux data now play a growing role in evaluating process- and satellitebased models (Law et al., 2000b). The network of EC towers (e.g., AmeriFlux) now covers a wide range of biomes in contrast to most previous efforts, which focused on individual sites or biomes (van Wijk and Bouten, 2002; Xiao et al., 2005a,b; Braswell et al., 2005; Williams et al., 2005; Dufrene et al., 2005). It is of clear value to understand the similarities and differences of GPP across time, space and biomes. The overarching goal of this study is to develop a LUE model (EC-LUE) for predicting daily GPP across biomes based on EC flux data. Specific objectives are to (1) derive consistent

Table 1

The structure and inputs of common light use efficiency models

\begin{tabular}{|c|c|c|c|}
\hline Model & $\varepsilon_{\mathrm{g}}$ or $\varepsilon_{\mathrm{n}}\left(\mathrm{g} \mathrm{C} \mathrm{m}^{-2} \mathrm{MJ}^{-1}\right.$ APAR $)$ & $\varepsilon_{0}\left(\mathrm{~g} \mathrm{C} \mathrm{m}^{-2} \mathrm{MJ}^{-1}\right.$ APAR $)$ & Reference \\
\hline \multicolumn{4}{|c|}{ Net primary production } \\
\hline CASA & $\varepsilon_{\mathrm{n}}=\varepsilon_{0} \times T_{\mathrm{s}} \times \mathrm{SM}$ & 0.389 & Potter et al. (1993) \\
\hline \multicolumn{4}{|c|}{ Gross primary production } \\
\hline \multirow[t]{2}{*}{ GLO-PEM } & $\varepsilon_{\mathrm{g}}=\varepsilon_{0} \times T_{\mathrm{s}} \times \mathrm{SM} \times \mathrm{VPD}$ & $55.2 \alpha^{\mathrm{a}}$ & Prince and Goward (1995) \\
\hline & $\varepsilon_{\mathrm{g}}=\varepsilon_{0} \times T_{\mathrm{s}} \times \mathrm{SM} \times \mathrm{VPD}$ & $2.76^{\mathrm{b}}$ & Prince and Goward (1995) \\
\hline MODIS-PSN & $\varepsilon_{\mathrm{g}}=\varepsilon_{0} \times T_{\mathrm{s}} \times \mathrm{VPD}$ & $0.604-1.259^{c}$ & Running et al. (2000) \\
\hline 3-PG & $\varepsilon_{\mathrm{g}}=\varepsilon_{0}$ & $1.8^{\mathrm{d}}$ & Landsberg and Waring (1997) \\
\hline \multirow[t]{2}{*}{ VPM } & $\varepsilon_{\mathrm{g}}=\varepsilon_{0} \times T_{\mathrm{s}} \times W$ & $2.208^{\mathrm{e}}$ & Xiao et al. (2005a) \\
\hline & $\varepsilon_{\mathrm{g}}=\varepsilon_{0} \times T_{\mathrm{s}} \times W$ & $2.484^{\mathrm{f}}$ & Xiao et al. (2005b) \\
\hline C-Fix model & $\varepsilon_{\mathrm{g}}=\varepsilon_{0}$ & 1.1 & Veroustraete et al. (2002) \\
\hline EC-LUE & $\varepsilon_{\mathrm{g}}=\varepsilon_{0} \times T_{\mathrm{s}} \times \mathrm{SM}$ & 2.14 & This study \\
\hline
\end{tabular}

$\mathrm{NPP}=\varepsilon_{\mathrm{n}} \times \mathrm{fPAR} \times \mathrm{PAR}$ or GPP $=\varepsilon_{\mathrm{g}} \times \mathrm{fPAR} \times \mathrm{PAR}$, where $\varepsilon_{\mathrm{n}}$ is realized light use efficiency for calculating NPP, and $\varepsilon_{\mathrm{g}}$ for GPP. Downward regulation scales for light use efficiency include: temperature $\left(T_{\mathrm{s}}\right)$, soil moisture index $(\mathrm{SM})$, water vapor pressure deficit (VPD) and canopy water content $(W) . \varepsilon_{0}$ is the potential light use efficiency in a few models.

${ }^{\text {a }}$ For $\mathrm{C}_{3}$ plants, and $\alpha$ is quantum yield.

${ }^{\mathrm{b}}$ For $\mathrm{C}_{4}$ plants.

${ }^{\mathrm{c}}$ For 11 standard global biome classes.

${ }^{\mathrm{d}}$ For forest ecosystems.

${ }^{\mathrm{e}}$ For evergreen needleleaf forests.

${ }^{\mathrm{f}}$ For moist tropical evergreen forests. An approximate conversion of 4.6 between MJ ( $\left.10^{6} \mathrm{~J}\right)$ and mol PPFD (Aber et al., 1996) is used in this study. 
daily GPP values from EC flux measurements collected from various forests, grasslands, and savannas, (2) develop a LUE model and optimize the parameters based on daily GPP estimates from EC measurements across biomes, (3) compare EC-LUE GPP predictions with MODIS products, and (4) investigate the major controlling factors of GPP during the growing season across major biomes.

\section{Methods and materials}

\subsection{Description of the EC-LUE model}

The algorithms for calculating PPAR and realized LUE, two important variables in the EC-LUE model (Eq. (1)), are described below. APAR combines the meteorological constraint of how much sunlight reaches a site with the ecological constraint of the amount of leaf area absorbing the solar energy, thus avoiding many complexities of canopy micrometeorology and carbon balance theory. Using a radiative transfer model, Myneni and Williams (1994) found a linear relationship between fPAR and NDVI for a large set of different vegetation-soil-atmosphere conditions:

$\mathrm{fPAR}=a \times \mathrm{NDVI}+b$

where $a$ and $b$ are empirical constants. The intercept of the relationship between fPAR and NDVI is generally negative, and the ratio of $a$ to $b$ indicates bare soil NDVI when fPAR is zero. In our study, $a$ and $b$ are set to 1.24 and -0.168 according to Sims et al. (2005), and NDVI is obtained directly from 1-km MODIS data.

The magnitude of LUE and its relationship to controlling factors are of crucial importance in the ECLUE model. It is assumed in the EC-LUE model that a universal invariant potential LUE $\left(\varepsilon_{\max }, \mathrm{g} \mathrm{C} \mathrm{m}^{-2} \mathrm{MJ}^{-1}\right.$ APAR) exists across all the sites and biomes. The potential LUE is reduced by non-optimal temperature or water stress:

$\varepsilon=\varepsilon_{\max } \times \min \left(T_{\mathrm{s}}, W_{\mathrm{s}}\right)$

where $T_{\mathrm{s}}$ and $W_{\mathrm{s}}$ are the downward-regulation scalars for the respective effects of temperature and moisture on LUE of vegetation. $T_{\mathrm{s}}$ and $W_{\mathrm{s}}$ vary between 0 and 1 with smaller values indicating a stronger negative impact. Min denotes the minimum value of $T_{\mathrm{s}}$ and $W_{\mathrm{s}}$. It should be noticed that in Eq. (3) we assumed that the impacts of temperature and moisture on LUE follow Liebig's law, i.e., LUE is only affected by the most limiting factor at any given time. Most other approaches assume that the impacts of temperature and moisture are multiplicative.
$T_{\mathrm{S}}$ is estimated based on the equation developed for the Terrestrial Ecosystem Model (TEM) (Raich et al., 1991):

$T_{\mathrm{s}}=\frac{\left(T-T_{\min }\right)\left(T-T_{\max }\right)}{\left[\left(T-T_{\min }\right)\left(T-T_{\max }\right)\right]-\left(T-T_{\mathrm{opt}}\right)^{2}}$

where $T_{\min }, T_{\max }$ and $T_{\text {opt }}$ are minimum, maximum and optimum air temperature $\left({ }^{\circ} \mathrm{C}\right)$ for photosynthetic activity, respectively. If air temperature falls below $T_{\min }$ or increases beyond $T_{\max }, T_{\mathrm{s}}$ is set to zero. In this study, $T_{\min }$ and $T_{\max }$ are set to 0 and $40{ }^{\circ} \mathrm{C}$, respectively, while $T_{\text {opt }}$ will be determined using nonlinear optimization.

Defining a function for quantifying the control of moisture availability on plant photosynthesis $\left(W_{\mathrm{s}}\right)$ has long been a challenge. Traditionally, soil moisture (Potter et al., 1993) and vapor pressure deficit (VPD) (Running et al., 2000) have been used to define the response function. However, these variables have their weaknesses. For example, it is difficult to characterize soil moisture conditions over large areas from either modeling or remote sensing. This limits the predictive power of any spatial GPP model that relies on soil moisture. On the other hand, VPD is not a good indicator of the spatial heterogeneity of soil moisture conditions across the landscape (e.g., slope versus valley) and it is not likely to be linearly related to soil water availability for which it is often used as a proxy. Here, we explore an alternative approach that uses the evaporative fraction (EF) to define the impact of moisture on photosynthesis:

$\mathrm{EF}=\frac{\mathrm{LE}}{\mathrm{LE}+H}$

where LE is EC-measured latent heat flux $\left(\mathrm{W} \mathrm{m}^{-2}\right)$, and $H$ is sensible heat flux $\left(\mathrm{W} \mathrm{m}^{-2}\right)$. The Bowen ratio $(\beta)$ is the ratio of energy available for sensible heating to energy available for latent heating (Lewis, 1995) and is related to EF by:

$\mathrm{EF}=\frac{1}{\beta+1}$

In this study, the water stress factor $W_{\mathrm{s}}$ equals EF. EF is a very good indicator of soil or vegetation moisture conditions because decreasing amounts of energy partitioned into latent heat flux suggests a stronger moisture limitation. A number of studies have used EF to represent moisture conditions of ecosystems (Kurc and Small, 2004; Zhang et al., 2004; Suleiman and Crago, 2004). In addition, EF can be derived from remotely sensed vegetation indices and land surface temperature products from satellites such as AVHRR and MODIS (Venturini et al., 2004), a major advantage of this approach. 


\subsection{EC flux data}

The EC flux data used in this study were downloaded from the AmeriFlux Internet site (http://public.ornl.gov/ ameriflux; AmeriFlux, 2001) and EuroFlux site (http:// www.fluxnet.ornl.gov/fluxnet/index.cfm; Valentini, 2003). Twenty-eight EC flux tower sites were included in this study (Table 2), from five major terrestrial biomes: deciduous broadleaf forest, mixed forest, evergreen needleleaf forest, grassland and savanna. Detailed information on the vegetation, climate, and soils at these sites is available at the AmeriFlux and EuroFlux Internet sites.

Eddy covariance systems directly measure net ecosystem exchange (NEE) rather than GPP. In order to estimate GPP, it is necessary to estimate daytime respiration $\left(R_{\mathrm{d}}\right)$ :

$\mathrm{GPP}=R_{\mathrm{d}}-\mathrm{NEE}_{\mathrm{d}}$ where $\mathrm{NEE}_{\mathrm{d}}$ is daytime NEE. Daytime ecosystem respiration $R_{\mathrm{d}}$ is usually estimated by using daytime temperature and an equation describing the temperature dependence of respiration, and the latter is usually developed from nighttime NEE measurements. Nighttime NEE represents nighttime respiration (autotrophic and heterotrophic) because plants do not photosynthesize at night. The following model (Marshall and Biscoe, 1980; Falge et al., 2002; Saito et al., 2005) was used to describe the effects of temperature on night-time NEE:

$\mathrm{NEE}_{\text {night }}=\gamma \times \mathrm{e}^{k T}$

where $\mathrm{NEE}_{\text {night }}$ is night-time ecosystem respiration, $T$ is average air temperature at night time. The parameters $\gamma$ and $k$ were determined using nonlinear optimization. Eq. (8) and daytime temperature were subsequently used to estimate daytime respiration $\left(R_{\mathrm{d}}\right)$. Because nighttime $\mathrm{CO}_{2}$ flux can be underestimated by eddy

Table 2

Name, location, annual mean temperature (AMT), annual precipitation (AP), and other characteristics of the study sites used for model calibration and validation

\begin{tabular}{|c|c|c|c|c|c|c|}
\hline Site & Latitude, longitude & Vegetation type & $\begin{array}{l}\text { AMT } \\
\left({ }^{\circ} \mathrm{C}\right)\end{array}$ & $\begin{array}{l}\mathrm{AP} \\
(\mathrm{mm})\end{array}$ & $\begin{array}{l}\text { Stand age } \\
\text { (year) }\end{array}$ & Reference \\
\hline \multicolumn{7}{|l|}{ Model calibration sites } \\
\hline Morgan Monroe & $39.32^{\circ} \mathrm{N}, 86.41^{\circ} \mathrm{W}$ & Deciduous broadleaf forest & 12.42 & 1030.5 & $60-90$ & Schmid et al. (2000) \\
\hline Sarrebourg & $48.67^{\circ} \mathrm{N}, 7.08^{\circ} \mathrm{E}$ & Deciduous broadleaf forest & 9.20 & 820 & 30 & Granier et al. (2000) \\
\hline Duke Hardwood & $35.97^{\circ} \mathrm{N}, 79.10^{\circ} \mathrm{W}$ & Deciduous broadleaf forest & 14.35 & 1154 & $80-100$ & Pataki and Oren (2003) \\
\hline Donaldson & $29.75^{\circ} \mathrm{N}, 82.16^{\circ} \mathrm{W}$ & Evergreen needleleaf forest & 21.70 & 1330 & $11-13$ & Gholz and Clark (2002) \\
\hline Metolius Young & $44.44^{\circ} \mathrm{N}, 121.57^{\circ} \mathrm{W}$ & Evergreen needleleaf forest & 7.68 & 403 & 15 & Law et al. (2000a) \\
\hline Metolius & $44.49^{\circ} \mathrm{N}, 121.62^{\circ} \mathrm{W}$ & Evergreen needleleaf forest & 8.37 & 577 & 250 and 50 & Law et al. (2000b) \\
\hline Howland Forest & $45.20^{\circ} \mathrm{N}, 68.74^{\circ} \mathrm{W}$ & Evergreen needleleaf forest & 6.65 & $523-1032$ & $95-140$ & Hollinger et al. $(1999,2004)$ \\
\hline Tharandt & $50.97^{\circ} \mathrm{N}, 13.63^{\circ} \mathrm{E}$ & Evergreen needleleaf forest & 7.50 & 824 & 140 & Kramer et al. (2002) \\
\hline Boreas NSA & $55.87^{\circ} \mathrm{N}, 98.48^{\circ} \mathrm{W}$ & Evergreen needleleaf forest & -3.55 & 420 & 120 and 90 & Goulden et al. (1998) \\
\hline Walnut River & $37.52^{\circ} \mathrm{N}, 96.86^{\circ} \mathrm{W}$ & Grassland & 13.10 & 1045.4 & & Song et al. (2005) \\
\hline Sylvania & $46.24^{\circ} \mathrm{N}, 89.35^{\circ} \mathrm{W}$ & Mixed forest & 6.14 & 408 & $1-350$ & Desai et al. (2005) \\
\hline Vaira Ranch & $38.41^{\circ} \mathrm{N}, 120.95^{\circ} \mathrm{W}$ & Grassland & 15.90 & 498 & & Baldocchi et al. (2004) \\
\hline \multicolumn{7}{|l|}{ Model validation sites } \\
\hline Goodwin Creek & $34.25^{\circ} \mathrm{N}, 89.97^{\circ} \mathrm{W}$ & Deciduous broadleaf forest & 16.10 & $700-1800$ & & \\
\hline Willow Creek & $45.91^{\circ} \mathrm{N}, 90.08^{\circ} \mathrm{W}$ & Deciduous broadleaf forest & 5.13 & 703 & $60-80$ & Bolstad et al. (2004) \\
\hline Austin Cary & $29.73^{\circ} \mathrm{N}, 82.22^{\circ} \mathrm{W}$ & Evergreen needleleaf forest & 21.70 & 1330 & 81 & Gholz and Clark (2002) \\
\hline Blodgett Forest & $38.89^{\circ} \mathrm{N}, 120.63^{\circ} \mathrm{W}$ & Evergreen needleleaf forest & 10.40 & 1290 & $6-7$ & Goldstein et al. (2000) \\
\hline Boreas NSA 1930 & $55.91^{\circ} \mathrm{N}, 98.52^{\circ} \mathrm{W}$ & Evergreen needleleaf forest & -2.88 & 499.82 & 76 & Goulden et al. (2006) \\
\hline Boreas NSA 1963 & $55.91^{\circ} \mathrm{N}, 98.38^{\circ} \mathrm{W}$ & Evergreen needleleaf forest & -2.87 & 502 & 43 & Goulden et al. (2006) \\
\hline Boreas NSA 1981 & $55.86^{\circ} \mathrm{N}, 98.49^{\circ} \mathrm{W}$ & Evergreen needleleaf forest & -2.86 & 500.34 & & Goulden et al. (2006) \\
\hline Metolius Mid & $44.45^{\circ} \mathrm{N}, 121.56^{\circ} \mathrm{W}$ & Evergreen needleleaf forest & 7.00 & 418 & 56 & Law et al. (2004) \\
\hline Hyytiala & $61.85^{\circ} \mathrm{N}, 24.28^{\circ} \mathrm{E}$ & Evergreen needleleaf forest & 3.50 & 640 & 30 & Kramer et al. (2002) \\
\hline Niwot Ridge & $40.03^{\circ} \mathrm{N}, 105.55^{\circ} \mathrm{W}$ & Evergreen needleleaf forest & 2.40 & 800 & 100 & Monson et al. (2002) \\
\hline Duke Pine & $35.98^{\circ} \mathrm{N}, 79.09^{\circ} \mathrm{W}$ & Evergreen needleleaf forest & 14.35 & 1154 & 17 & Stoy et al. (2006) \\
\hline Fort Peck & $48.31^{\circ} \mathrm{N}, 105.10^{\circ} \mathrm{W}$ & Grassland & 5.13 & 500 & & \\
\hline Duke Grass & $35.97^{\circ} \mathrm{N}, 79.09^{\circ} \mathrm{W}$ & Grassland & 14.35 & 1154 & & Novick et al. (2004) \\
\hline Lost Creek & $46.08^{\circ} \mathrm{N}, 89.98^{\circ} \mathrm{W}$ & Mixed forest & 5.02 & 648.5 & & Davis et al. (2003) \\
\hline UMBS & $45.56^{\circ} \mathrm{N}, 84.71^{\circ} \mathrm{W}$ & Mixed forest & 6.20 & 750 & 90 & Curtis et al. (2005) \\
\hline Tonzi Ranch & $38.43^{\circ} \mathrm{N}, 120.97^{\circ} \mathrm{W}$ & Savanna & 15.4 & 494 & & Baldocchi et al. (2004) \\
\hline
\end{tabular}


covariance measurements under stable conditions (Baldocchi, 2003), the data included in this study were limited to conditions when the friction velocity $\left(u^{*}\right)$ exceeded $0.25 \mathrm{~m} \mathrm{~s}^{-1}$. On average, $48 \%$ of the nighttime data was rejected due to insufficient turbulence. The data rejected varied among sites from 76\% (Duke hardwood) to $16 \%$ (Boreas 1930). Although many variants of Eq. (8) have been proposed (Wang et al., 2003; Gilmanov et al., 2005), our results indicated that Eq. (8) was the most reliable and robust across all sites because regressions of other methods sometimes tended to yield unstable parameters.

MODIS data used in the model were MODIS ASCII subset data generated with Collection 4 or later algorithms, and were downloaded directly from the AmeriFlux web site. MODIS NDVI 16-day composites at 1-km spatial resolution were the basis for calculating the fPAR for the flux sites. Only the NDVI values of the pixel containing the tower were used. Quality control (QC) flags, which signal cloud contamination in each pixel, were examined to screen and reject NDVI data of insufficient quality. Daily NDVI values were derived from two consecutive 16-day composites by linear interpretation.

\subsection{Nonlinear optimization and statistical analysis}

The nonlinear regression procedure (Proc NLIN) in the Statistical Analysis System (SAS, SAS Institute Inc., Cary, NC, USA) was applied to two calculations: (1) to determine the parameter values in the equation describing the temperature dependence of ecosystem respiration (i.e., Eq. (8)), and (2) to optimize the values for $T_{\text {opt }}$ and $\varepsilon_{\text {max }}$ in the EC-LUE model across all the calibration sites.

Four metrics were used to evaluate the performance of the EC-LUE model in this study, including these four:

(1) The coefficient of determination, $R^{2}$, representing how much variation in the observations was explained by the model.

(2) Absolute predictive error (PE), quantifying the difference between simulated and observed values.

(3) Relative predictive error (RPE), computed as:

$\mathrm{RPE}=\frac{\bar{S}-\bar{O}}{\bar{O}} \times 100$

where $\bar{S}$ and $\bar{O}$ are mean simulated and mean observed values, respectively.

(4) Kendall's coefficient of rank correlation $\tau$ (Kanji, 1999), which was used to quantify the agreement between the simulated and estimated from EC measurements seasonal patterns of GPP. The Kendall coefficient measured the tendency coherence between predicted and observed GPP by comparing the ranks assigned to successive pairs. If $O_{j}-O_{i}$ and $S_{j}-S_{i}$ have the same sign (i.e., positive or negative), the pair would be concordant. Otherwise, the pair would be discordant. With $n$ observations, we can form $n(n-1) / 2$ pairs. Let $C$ stand for the number of concordant pairs and $D$ stand for the number of discordant pairs, then the Kendall concordance coefficient can be calculated as follows:

$\tau=\frac{C-D}{n(n-1) / 2}$

From the definition, it can be seen that the Kendall coefficient varies from -1 (when $C=0$ ) to 1 (when $D=0$ ). A preponderance of concordant pairs would result in a value close to 1 , indicating a strong positive relationship between the seasonal patterns of observed and simulated GPP; a preponderance of discordant pairs would result in a negative value close to -1 , indicating a strong negative relationship between the seasonal patterns.

\section{Results}

\subsection{Model calibration}

Twelve sites were selected to develop the EC-LUE model. These sites spanned from the subtropical to boreal regions, covered several dominant natural ecosystem types including: evergreen needleleaf forest, mixed forest, deciduous broadleaf forest, grassland and savanna (Table 2). The calibrated values for optimal temperature $\left(T_{\text {opt }}\right)$ and potential LUE $\left(\varepsilon_{\max }\right)$ were $20.33{ }^{\circ} \mathrm{C}$ and $2.14 \mathrm{~g} \mathrm{C} \mathrm{m}^{-2} \mathrm{MJ}^{-1}$ APAR, respectively.

Fig. 1 shows the range of predicted GPP and estimated GPP from EC measurements at the 12 calibration sites. Collectively, the EC-LUE model explained about $85 \%$ of the variation of daily GPP estimated across all these sites (Fig. 2). There were no significant systematic errors in model predictions. Individually, the coefficients of determination $\left(R^{2}\right)$ varied from 0.63 at Donaldson site to 0.93 at the Walnut River site, with all of them being statistically significant at $p<0.05$ (Table 3). Although the EC-LUE model explained significant amounts of GPP variability at the individual sites, large differences between predicted 

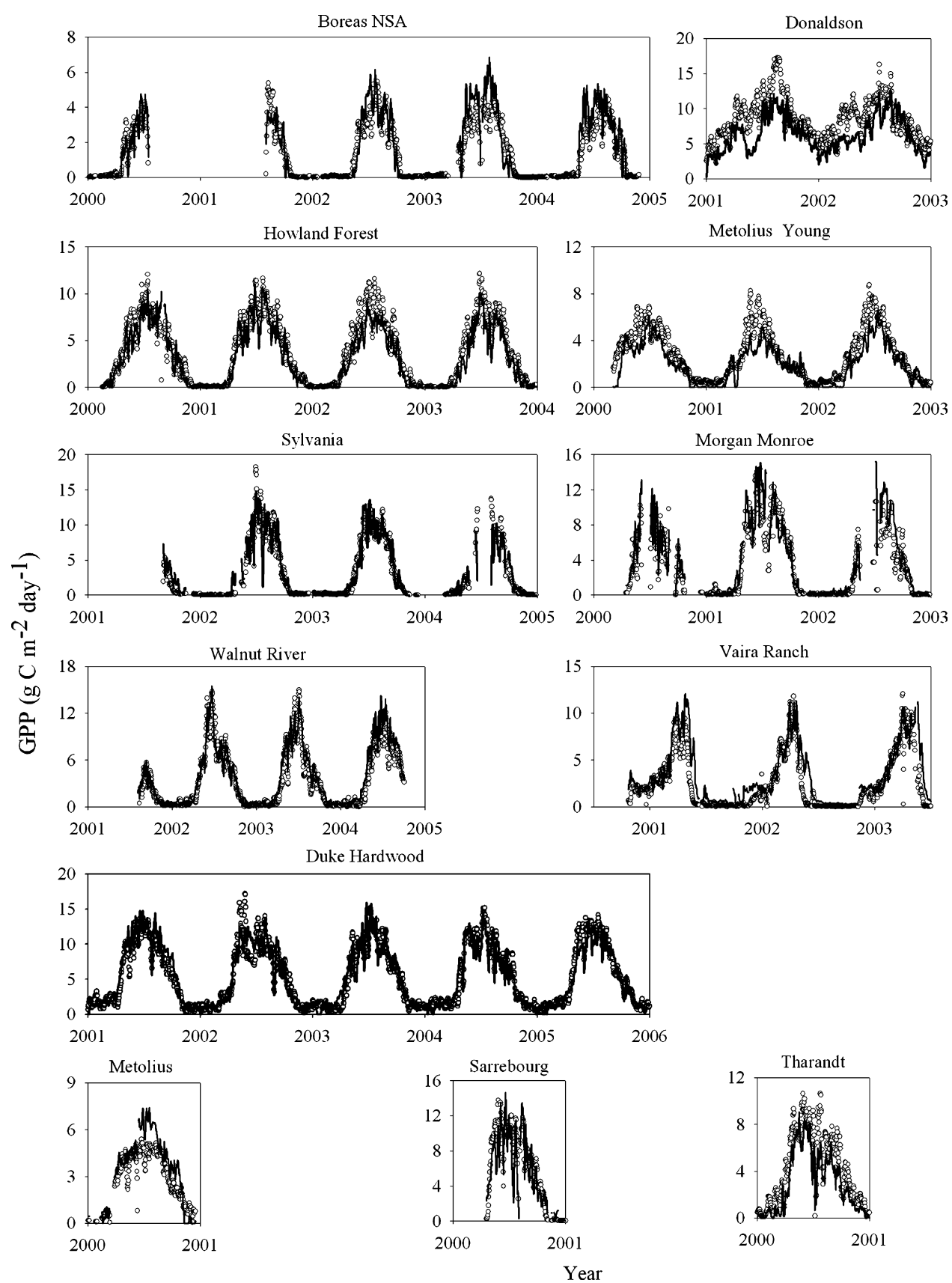

Fig. 1. Daily variation of predicted GPP and estimated GPP from EC measurements at model calibration sites. The black solid lines represent the predicted GPP, and the open circle dots represent estimated GPP.

GPP and estimated GPP values from EC measurements still existed at a few sites. The model underestimated GPP at Donaldson, Metolius young and Tharandt with the relative predictive errors being $-25 \%,-25 \%$ and $-30 \%$, respectively (Table 3 ). The discrepancies between predicted GPP and estimated GPP from EC measurements values occurred mainly in the initial stages of the growing seasons of 2001 and 2002 at
Donaldson (Fig. 1). At Tharandt, although the EC-LUE model explained $89 \%$ of the GPP variation, the GPP values were consistently underestimated throughout the growing season (Fig. 1). Predicted values were higher than estimated GPP at Metolius and Vaira Ranch with $\mathrm{PE}$ values being $0.63 \mathrm{~g} \mathrm{C} \mathrm{m}^{-2} \mathrm{day}^{-1}$ and $0.81 \mathrm{~g} \mathrm{C} \mathrm{m}^{-2}$ day $^{-1}$ and $\mathrm{RPE}$ values being $22 \%$ and $38 \%$, respectively. Specifically, the EC-LUE model 


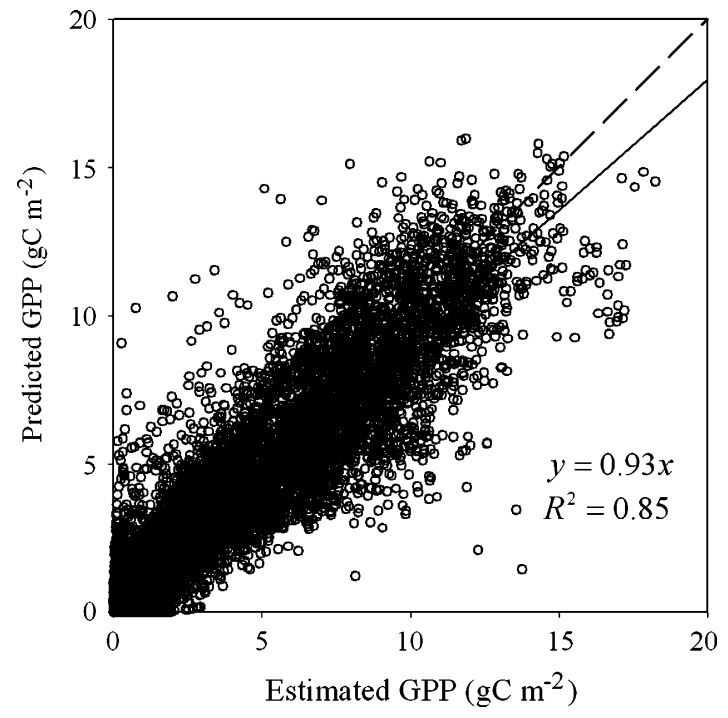

Fig. 2. Predicted vs. the estimated GPP at the model calibration sites in Table 1 . The short dash line is 1:1 line and the solid line is linear regression line.

overestimated GPP during the mid-growing season at Metolius (Fig. 1). At the other seven sites, the EC-LUE model gave good predictions with RPE values lower than $20 \%$ (Table 3 ).

The predicted GPP and estimated GPP from EC measurements time series at the calibration sites demonstrated distinct seasonal cycles and matched well (Fig. 1). At most sites, GPP values were near zero in the winter season because low temperature and frozen soil inhibited photosynthetic activities. The evergreen needleleaf forest at Donaldson still maintains high ecosystem production in winter because it is located at low latitude with adequate temperature. The starting and end dates of the predicted GPP and estimated GPP from EC measurements agreed well across all sites. The average Kendall's correlation coefficient for the 12 calibration sites was 0.91 , indicating strong seasonal concordance between the simulated and estimated GPP from EC measurements (Table 3).

\subsection{Model validation}

We added 16 sites, including various ecosystem types, to check the performance of the EC-LUE model (Table 2). The EC-LUE model successfully predicted the magnitudes and seasonal variations of the estimated GPP from EC measurements at these new sites (Fig. 3). Model performance was similar to that at the calibration sites and explained 77\% of the GPP variations across all 16 sites (Fig. 4). No significant systematic errors were found in the EC-LUE model across the validation sites.
At individual sites, the EC-LUE model explained 59$96 \%$ of the GPP variability with no apparent biases in any one biome (Table 3 ).

However, large differences between predicted and estimated GPP still existed in a few sites, including the three Boreas NSA burn sites, Lost Creek, Fort Peck and Tonzi Ranch. At the three Boreas NSA burn sites, the RPE varied from $-44 \%$ to $-23 \%$. Predicted GPP values were higher than estimated GPP at Fort Peck, Lost Creek and Tonzi Ranch with RPE values of $41 \%, 46 \%$ and $31 \%$, respectively. At the other 10 sites, the RPE values were lower than $15 \%$.

The predicted seasonal patterns as well as beginning and end of growing seasons agreed well with the estimated values from EC measurements at all validation sites (Fig. 3). The average Kendall's correlation coefficient from the 16 validation sites was 0.88 , indicating that predicted GPP had a strong seasonal coherence with estimated GPP from EC measurements.

\subsection{Comparison with the MODIS-GPP product}

The MOD17 GPP products were level-4, 1-km global data collections, downloaded from the FLUXNET sites directly. We compared results generated from the EC-LUE model and MODIS-GPP products at 28 sites. The EC-LUE results were summed over 8-day periods to match the time scale of MODIS-GPP products. Comparison was performed only when all three estimates of GPP were available: estimated GPP from FLUXNET sites, predicted GPP by the EC-LUE model and MODIS-GPP products.

Overall, the EC-LUE model performed better than the MODIS algorithms at these sites according to the values of $R^{2}, \mathrm{PE}$ and RPE (Table 4). The EC-LUE model could explain $82 \%$ of the variation in the 8-day GPP compared with just $44 \%$ by the MODIS-GPP product (Fig. 5). The PE values of the EC-LUE model and MODIS-GPP were significantly correlated with the estimated GPP from EC measurements (Fig. 5). However, it is apparent that the correlation of EC-LUE was strongly affected by one extreme value (GPP $=66.69$ at Donaldson). Without this point, $P E$ values of the EC-LUE model were independent of estimated GPP from EC measurements. As to the RPE values, significant correlation with the estimated GPP from EC measurements was only found in the MODISGPP product. However, the slopes of EC-LUE in the regression equation of $\mathrm{PE}$ and RPE with estimated GPP from EC measurements were closer to zero, with lower $R^{2}$ and intercepts that were comparable to the MODISGPP product. Overall, the EC-LUE model offered better predictions of GPP than the MODIS-GPP product. 
Table 3

Predicted results of the EC-LUE model for calibration and validation sites

\begin{tabular}{|c|c|c|c|c|c|c|c|}
\hline Site & $R^{2}$ & Pred $^{\mathrm{a}}$ & $\mathrm{Est}^{\mathrm{b}}$ & $\mathrm{PE}$ & RPE (\%) & $\tau$ & $N^{\mathrm{c}}$ \\
\hline \multicolumn{8}{|l|}{ Model calibration sites } \\
\hline Morgan Monroe & 0.82 & 4.11 & 3.51 & 0.60 & 0.17 & 0.90 & 777 \\
\hline Sarrebourg & 0.83 & 5.72 & 6.03 & -0.31 & -0.05 & 0.91 & 239 \\
\hline Duke Hardwood & 0.91 & 5.36 & 5.31 & 0.05 & 0.01 & 0.95 & 1845 \\
\hline Donaldson & 0.63 & 6.29 & 8.36 & -2.07 & -0.25 & 0.79 & 738 \\
\hline Metolius Young & 0.81 & 2.03 & 2.72 & -0.69 & -0.25 & 0.89 & 1044 \\
\hline Metolius & 0.85 & 3.50 & 2.87 & 0.63 & 0.22 & 0.92 & 298 \\
\hline Howland Forest & 0.90 & 3.19 & 3.75 & -0.56 & -0.15 & 0.94 & 1393 \\
\hline Tharandt & 0.89 & 2.92 & 4.17 & -1.25 & -0.30 & 0.94 & 368 \\
\hline Boreas NSA & 0.83 & 1.51 & 1.39 & 0.12 & 0.09 & 0.91 & 1303 \\
\hline Walnut River & 0.93 & 3.84 & 3.46 & 0.38 & 0.11 & 0.96 & 1160 \\
\hline Sylvania & 0.89 & 3.22 & 3.19 & 0.03 & 0.01 & 0.94 & 945 \\
\hline Vaira Ranch & 0.80 & 2.93 & 2.12 & 0.81 & 0.38 & 0.89 & 1147 \\
\hline \multicolumn{8}{|l|}{ Model validation sites } \\
\hline Goodwin Creek & 0.77 & 4.71 & 4.54 & 0.17 & 0.04 & 0.88 & 822 \\
\hline Willow Creek & 0.73 & 3.81 & 3.47 & 0.34 & 0.10 & 0.85 & 1161 \\
\hline Austin Cary & 0.72 & 5.08 & 5.48 & -0.41 & -0.07 & 0.84 & 283 \\
\hline Blodgett Forest & 0.60 & 4.87 & 5.48 & -0.61 & -0.11 & 0.77 & 1352 \\
\hline Boreas NSA 1930 & 0.79 & 1.84 & 3.04 & -1.20 & -0.39 & 0.89 & 107 \\
\hline Boreas NSA 1963 & 0.96 & 0.90 & 1.62 & -0.72 & -0.44 & 0.97 & 211 \\
\hline Boreas NSA 1981 & 0.60 & 1.80 & 2.35 & -0.55 & -0.23 & 0.77 & 62 \\
\hline Metolius Mid & 0.64 & 2.94 & 3.03 & -0.09 & -0.03 & 0.79 & 998 \\
\hline Hyytiala & 0.94 & 2.42 & 2.50 & -0.08 & -0.03 & 0.97 & 328 \\
\hline Niwot Ridge & 0.87 & 2.39 & 2.39 & 0.00 & 0.00 & 0.93 & 1429 \\
\hline Duke Pine & 0.78 & 6.00 & 6.85 & -0.85 & -0.12 & 0.88 & 2168 \\
\hline Fort Peck & 0.90 & 2.93 & 2.07 & 0.85 & 0.41 & 0.94 & 159 \\
\hline Duke Grass & 0.83 & 2.11 & 2.34 & -0.23 & -0.10 & 0.91 & 1108 \\
\hline Lost Creek & 0.87 & 3.55 & 2.43 & 1.11 & 0.46 & 0.93 & 1285 \\
\hline UMBS & 0.92 & 5.75 & 5.72 & 0.03 & 0.00 & 0.96 & 681 \\
\hline Tonzi Ranch & 0.59 & 2.76 & 2.10 & 0.65 & 0.31 & 0.77 & 938 \\
\hline
\end{tabular}

\subsection{Environmental controls on daily GPP}

The relationship of estimated GPP from EC measurements to APAR at 12 calibration sites during the growing season was a strong linear relationship. However, the amount of GPP variation explained by APAR variation was site-dependent. For example, APAR can explain $78 \%$ of GPP variation at Walnut River and only $26 \%$ at Boreas NSA.

At all sites, the temperature and moisture indexes had distinct seasonal patterns (Figs. 6 and 7). The values of thermal index were close to zero in the winter, except for some sites located in lower latitudes or with a Mediterranean climate such as Goodwin Creek, Donaldson, Austin Cary, Tonzi Ranch and Vaira Ranch. Compared with the thermal index, the moisture index demonstrated more diverse and complex variations. The moisture index at most sites had a similar seasonal trend to that of thermal index, characterized by very low values in the winter and higher values during the growing season. At some sites such as Metolius Young and Metolius Mid, higher values of moisture index appeared during the winter rather than during the growing season because of the warm and dry summers and wet and cool winters (Law et al., 2001). For sites with a Mediterranean climate (e.g., Vaira Ranch and Tonzi Ranch), the growing season was from winter to the following spring, and the moisture index was close to zero during summer and autumn, opposite of the seasonality of the thermal index.

At most sites, water availability was the controlling factor of LUE except at the beginning and end of the growing season when temperature affected LUE (Figs. 6 and 7). For example, the thermal index was lower than the soil moisture index only at the beginning and end of the growing season at Metolius Young, suggesting that temperature rather than moisture was the controlling factor on LUE during these time periods. 

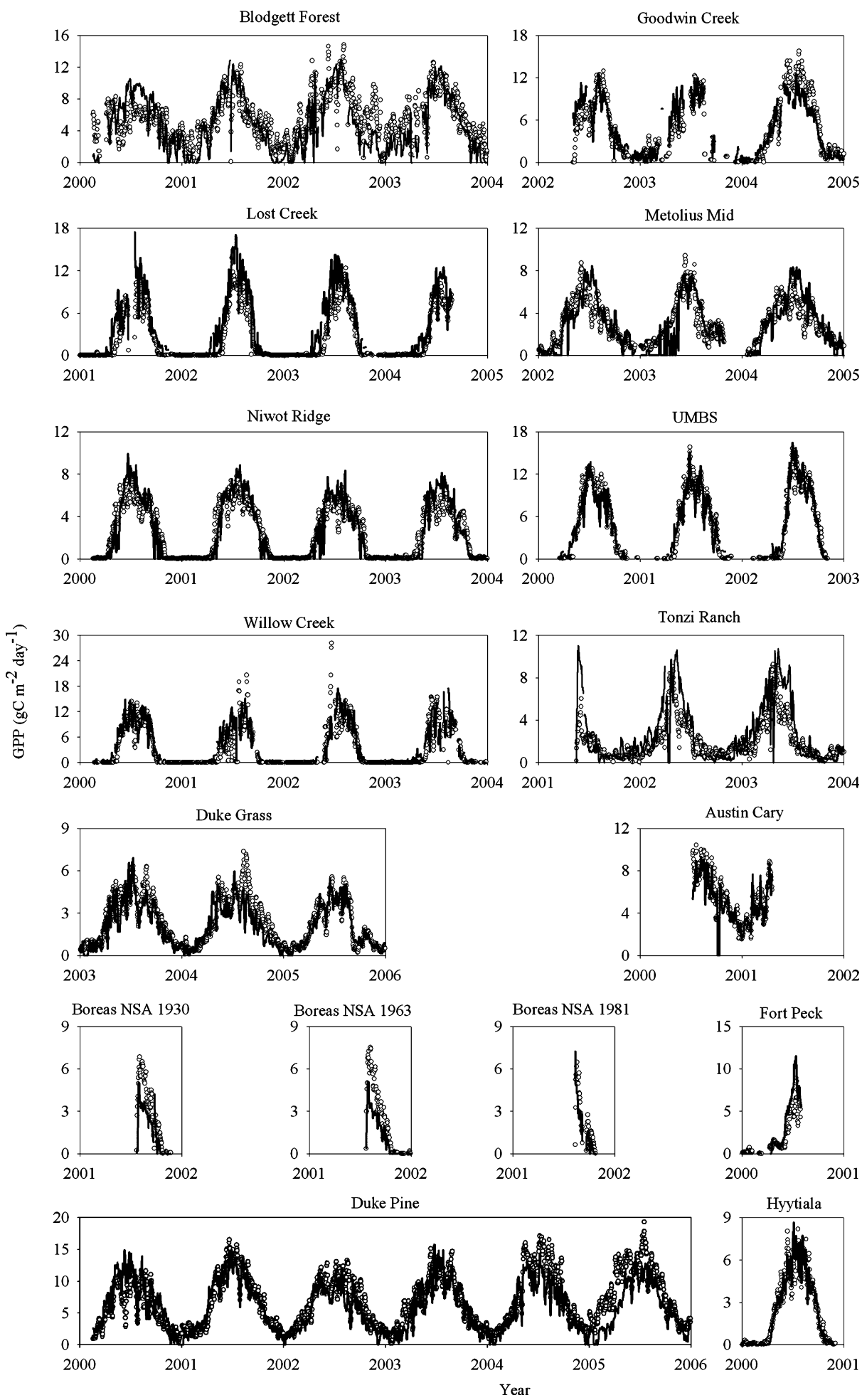

Fig. 3. Daily variation of predicted GPP and estimated GPP from EC measurements at model test sites. The black solid lines represent predicted GPP, and the open circle dots represent estimated GPP. 


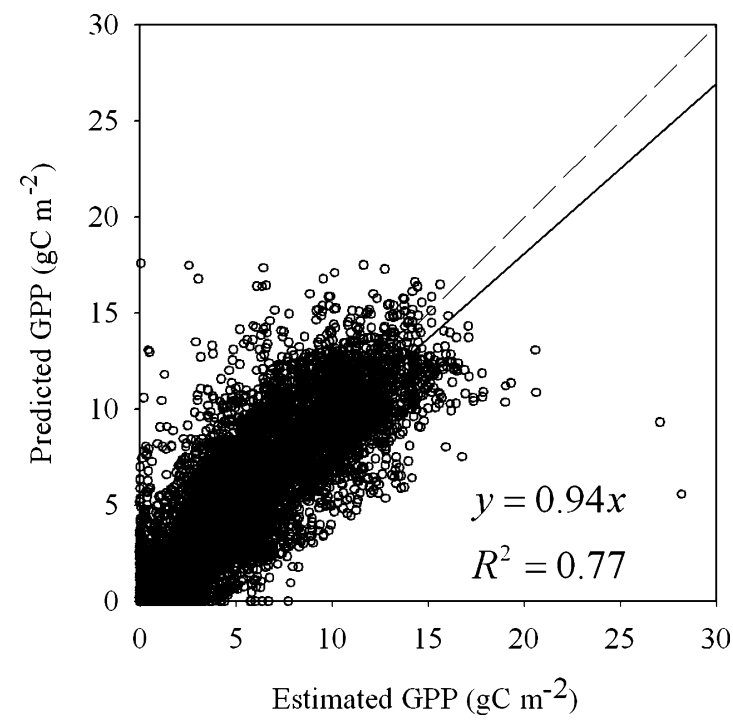

Fig. 4. Predicted vs. the estimated GPP at the model test sites in Table 1. The short dash line is 1:1 line and the solid line is linear regression line.

However, because Tonzi Ranch and Vaira Ranch share a Mediterranean climate, they were biologically active during the winter and early spring and became dormant during the summer as temperature was out of phase with precipitation. Moisture was the controlling factor not only for initiating the beginning of the growing season at Tonzi Ranch and Vaira Ranch but also for the length of the whole growing season. Thermal resources were always ample at the low-altitude sites such as Donaldson and Goodwin Creek, and moisture was the only limiting factor for the realization of the potential LUE.

\section{Discussion}

\section{1. $f P A R$}

fPAR in the EC-LUE model is calculated from the NDVI. Although this algorithm was empirically based on ground measurements (Sims et al., 2005), it has a strong theoretical basis (Myneni and Williams, 1994). This study used MODIS/Terra NDVI products of 1-km resolution, directly downloaded from the FLUXNET sites. No attempt was made to improve the quality of the NDVI data. Any noises or errors in the NDVI values, therefore, would have been transferred to GPP predictions. MODIS/Terra NDVI products were generated from MODIS Terra surface reflectance after correcting for the effects of cloud contamination, ozone absorption, and aerosols, and adjusted to nadir and standard sun angles with use of BRDF models (http:// edcdaac.usgs.gov/modis/mod13a2.asp). NDVI noises and errors are inevitable at the flux tower footprint scale. These will contribute proportionally to the errors in fPAR calculation, and ultimately to GPP prediction. Although NDVI values saturate in multi-layer closed canopies with LAI values greater than 4-6, the successful application of the linear relationship between
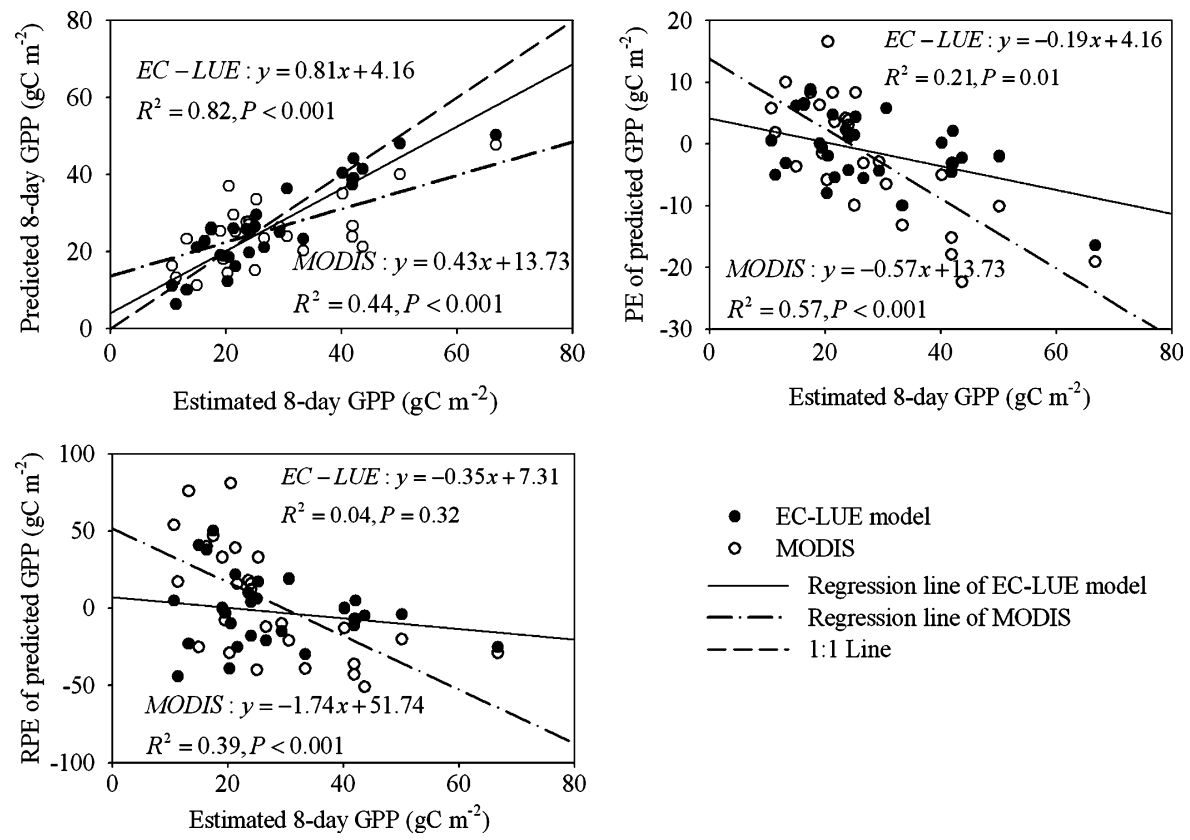

- EC-LUE model

- MODIS

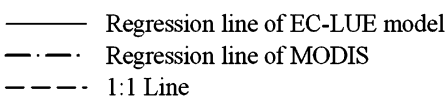

- - 1:1 Line

Fig. 5. Comparison with estimated 8-day GPP from EC measurements and predicted GPP by the EC-LUE model and MODIS-GPP product. 
Table 4

Comparison between the EC-LUE model and MODIS-GPP product

\begin{tabular}{|c|c|c|c|c|c|c|c|c|c|c|}
\hline \multirow[t]{2}{*}{ Site } & \multirow[t]{2}{*}{$\mathrm{Est}^{\mathrm{a}}$} & \multirow[t]{2}{*}{$N^{\mathrm{b}}$} & \multicolumn{4}{|c|}{ EC-LUE model } & \multicolumn{4}{|c|}{ MODIS-GPP } \\
\hline & & & Pred $^{\mathrm{c}}$ & $R^{2}$ & $\mathrm{PE}$ & RPE & Pred $^{\mathrm{d}}$ & $R^{2}$ & $\mathrm{PE}$ & RPE \\
\hline Morgan Monroe & 25.27 & 108 & 29.60 & 0.88 & 4.34 & 0.17 & 33.53 & 0.71 & 8.26 & 0.33 \\
\hline Sarrebourg & 43.67 & 33 & 41.43 & 0.89 & -2.24 & -0.05 & 21.23 & 0.81 & -22.44 & -0.51 \\
\hline Donaldson & 66.69 & 92 & 50.23 & 0.66 & -16.47 & -0.25 & 47.62 & 0.65 & -19.07 & -0.29 \\
\hline Metolius Young & 21.68 & 131 & 16.18 & 0.84 & -5.49 & -0.25 & 25.23 & 0.76 & 3.56 & \\
\hline Metolius & 21.36 & 40 & 26.07 & 0.91 & 4.71 & 0.22 & 29.66 & 0.76 & 8.30 & \\
\hline Howland Forest & 29.33 & 178 & 24.99 & 0.94 & -4.35 & -0.15 & 26.41 & 0.85 & -2.92 & -0.10 \\
\hline Tharandt & 33.33 & 46 & 23.34 & 0.92 & -9.99 & -0.30 & 20.17 & 0.77 & -13.16 & -0.39 \\
\hline Boreas NSA & 10.68 & 131 & 11.20 & 0.87 & 0.52 & 0.05 & 16.43 & 0.78 & 5.75 & \\
\hline Walnut River & 25.06 & 111 & 26.49 & 0.96 & 1.43 & 0.06 & 15.11 & 0.84 & -9.95 & -0.40 \\
\hline Duke Hardwood & 42.09 & 138 & 44.09 & 0.93 & 2.01 & 0.05 & 38.98 & 0.79 & -3.11 & -0.07 \\
\hline Sylvania & 24.06 & 99 & 25.07 & 0.95 & 1.02 & 0.04 & 27.02 & 0.83 & 2.96 & 0.12 \\
\hline Vaira Ranch & 16.35 & 147 & 22.61 & 0.84 & 6.26 & 0.38 & 22.81 & 0.02 & 6.46 & 0.40 \\
\hline Goodwin Creek & 30.61 & 65 & 36.38 & 0.84 & 5.77 & 0.19 & 24.07 & 0.53 & -6.54 & -0.21 \\
\hline Willow Creek & 23.59 & 171 & 25.87 & 0.82 & 2.28 & 0.10 & 27.73 & 0.71 & 4.14 & 0.18 \\
\hline Austin Cary & 41.91 & 37 & 38.79 & 0.86 & -3.11 & -0.07 & 26.71 & 0.69 & -15.20 & -0.36 \\
\hline Blodgett Forest & 41.88 & 176 & 37.32 & 0.71 & -4.57 & -0.11 & 23.90 & 0.17 & -17.98 & -0.43 \\
\hline Boreas NSA 1930 & 20.34 & 16 & 12.31 & 0.92 & -8.03 & -0.39 & 14.53 & 0.33 & -5.81 & -0.29 \\
\hline Boreas NSA 1963 & 11.40 & 30 & 6.36 & 0.98 & -5.05 & -0.44 & 13.29 & 0.82 & 1.88 & 0.17 \\
\hline Boreas NSA 1981 & 13.22 & 11 & 10.13 & 0.90 & -3.09 & -0.23 & 23.23 & 0.37 & 10.01 & 0.76 \\
\hline Metolius Mid & 24.00 & 62 & 19.75 & 0.77 & -4.26 & -0.18 & 27.84 & 0.78 & 3.83 & 0.16 \\
\hline Hyytiala & 19.55 & 42 & 18.91 & 0.96 & -0.64 & -0.03 & 17.99 & 0.90 & -1.56 & -0.08 \\
\hline Niwot Ridge & 19.07 & 179 & 19.08 & 0.90 & 0.01 & 0.00 & 25.35 & 0.86 & 6.27 & 0.33 \\
\hline Fort Peck & 14.98 & 22 & 21.16 & 0.94 & 6.18 & 0.41 & 11.28 & 0.82 & -3.70 & -0.25 \\
\hline Tonzi Ranch & 26.65 & 122 & 21.11 & 0.66 & -5.54 & -0.21 & 23.56 & 0.32 & -3.09 & -0.12 \\
\hline Lost creek & 17.42 & 142 & 26.22 & 0.90 & 8.79 & 0.50 & 25.68 & 0.82 & 8.26 & 0.47 \\
\hline UMBS & 40.16 & 97 & 40.35 & 0.95 & 0.19 & 0.00 & 35.08 & 0.81 & -5.07 & -0.13 \\
\hline Duke Grass & 20.47 & 46 & 18.51 & 0.93 & -1.96 & -0.10 & 37.01 & 0.87 & 16.54 & 0.81 \\
\hline Duke Pine & 50.11 & 179 & 48.07 & 0.84 & -2.03 & -0.04 & 40.01 & 0.77 & -10.09 & -0.20 \\
\hline
\end{tabular}

${ }^{\mathrm{a}}$ Estimated GPP from EC flux tower data $\left(\mathrm{g} \mathrm{C} \mathrm{m}^{-2} 8\right.$ days $\left.^{-1}\right)$.

b Total number.

c Average predicted GPP by the EC-LUE model $\left(\mathrm{g} \mathrm{C} \mathrm{m}^{-2} 8\right.$ days $\left.^{-1}\right)$.

${ }^{\mathrm{d}}$ Average predicted GPP of MODIS-GPP products $\left(\mathrm{g} \mathrm{C} \mathrm{m}^{-2} 8\right.$ days $\left.^{-1}\right)$.

NDVI and fPAR in the EC-LUE model across these various test sites suggested that NDVI saturation is not a limitation for estimating fPAR, when compared to the traditional approach discussed below.

Another very commonly used method for calculating fPAR is based on the Beer-Lambert law (Ruimy et al., 1999):

$\mathrm{fPAR}=0.95 \times(1-\exp (-k \times \mathrm{LAI}))$

where $k$ is the light extinction coefficient $(k=0.5)$, and LAI is the leaf area index $\left(\mathrm{m}^{2} \mathrm{~m}^{-2}\right)$. It is worthwhile to compare the similarity and differences of the fPAR values derived from NDVI and LAI. Because LAI data were scarce, comparison was only possible at a few sites. According to Granier et al. (2000), the averaged LAI value at the Sarrebourg site was $4.9 \pm 0.4 \mathrm{~m}^{2} \mathrm{~m}^{-2}$ over the growing season of 1996-1997. Based on the BeerLambert law, the fPAR value of Sarrebourg would be 0.87 . The fPAR value for Morgan Monroe would also be
0.87 with a LAI of $4.9 \mathrm{~m}^{2} \mathrm{~m}^{-2}$ (Curtis et al., 2002). The fPAR values at Sarrebourg and Morgan Monroe derived from LAI were very close to those derived from NDVI in this study (0.89 and 0.86, respectively for Sarrebourg and Morgan Monroe, Table 5). Similarity of the fPAR values derived from these two methods can also be seen at the Metolius Young and old stands, two evergreen needleleaf forest ecosystems. The Metolius Young ponderosa pine forest was clear-cut in 1978 and had not yet reached its maximum canopy cover. The LAI of the Metolius Young forest was $2.0 \mathrm{~m}^{2} \mathrm{~m}^{-2}$, only about half of that of the Metolius mature ponderosa pine forest $\left(4.3 \mathrm{~m}^{2} \mathrm{~m}^{-2}\right)$ (Law et al., 2001). The corresponding LAI-derived fPAR values were 0.60 and 0.83 for the Metolius Young and mature stands, respectively, which are very similar to the NDVI-derived values of 0.58 and 0.75 from this study. The slightly higher LAI-derived fPAR values might be explained by the time period they cover: LAI values from Law et al. (2001) were measured in July 1999, the peak of 

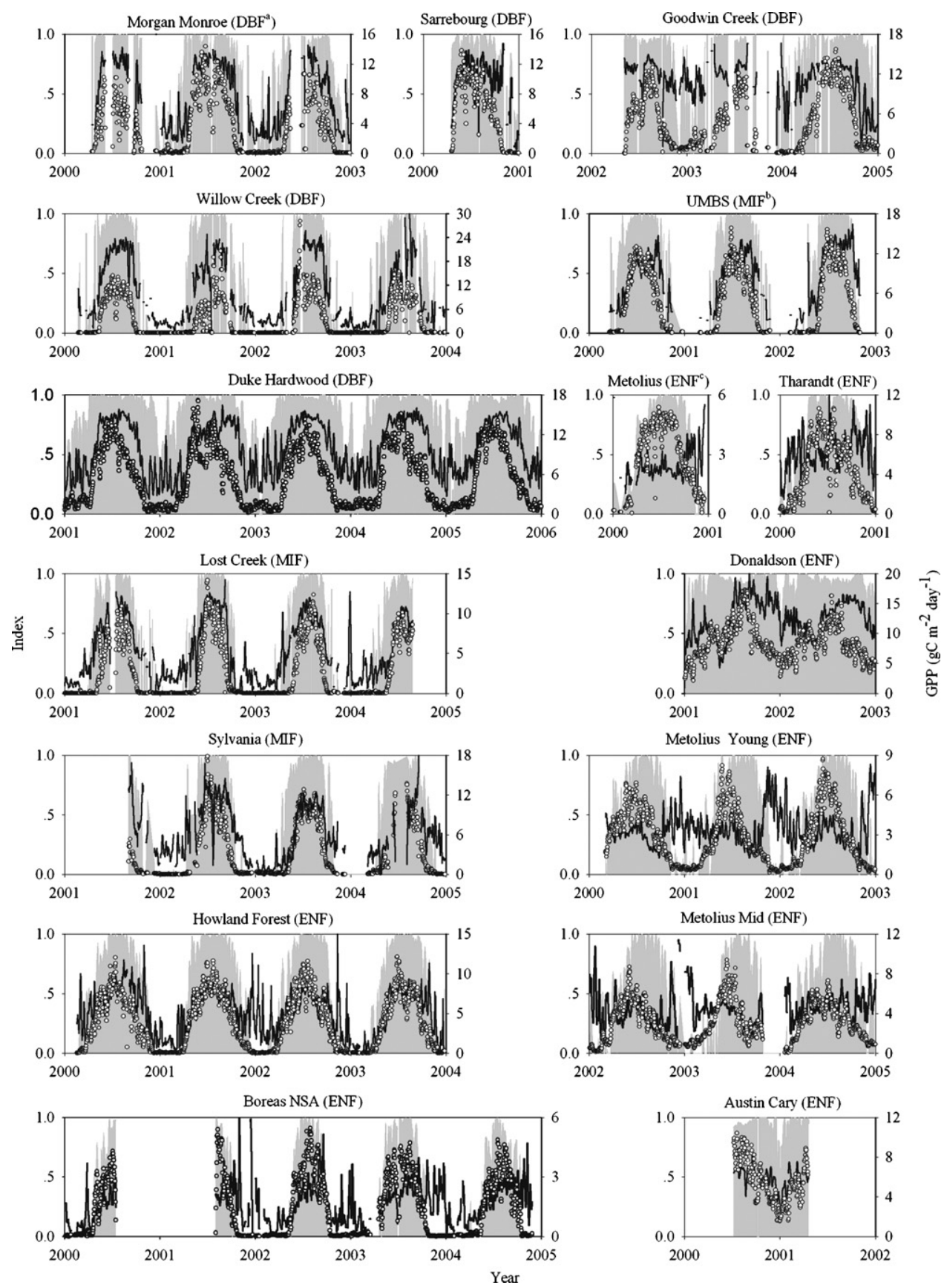

Fig. 6. Daily dynamics of temperature and moisture indices with estimated GPP. The gray shadows represent temperature index. The black solid lines represent moisture index. The black filled dots represent GPP. ${ }^{\mathrm{a}}$ Deciduous broadleaf forest; ${ }^{\mathrm{b}}$ Mixed forest; ${ }^{\mathrm{c}}$ Evergreen needleleaf forest.

the growing season, while the NDVI-derived values were based on the mean NDVI value over the entire growing season. The fPAR values of grasslands and savannas were lower than those of forest ecosystems because of lower canopy cover. The fPAR values were 0.57 for Walnut River, 0.62 for Vaira Ranch, and 0.47 for Tonzi Ranch. The seasonal trend of the PPAR values at Vaira Ranch found in this study was similar to that found by $\mathrm{Xu}$ and Baldocchi (2004).

\subsection{Environmental controls on daily GPP}

Our study's finding of a strong linear relationship between daily GPP and APAR at all sites differs from 

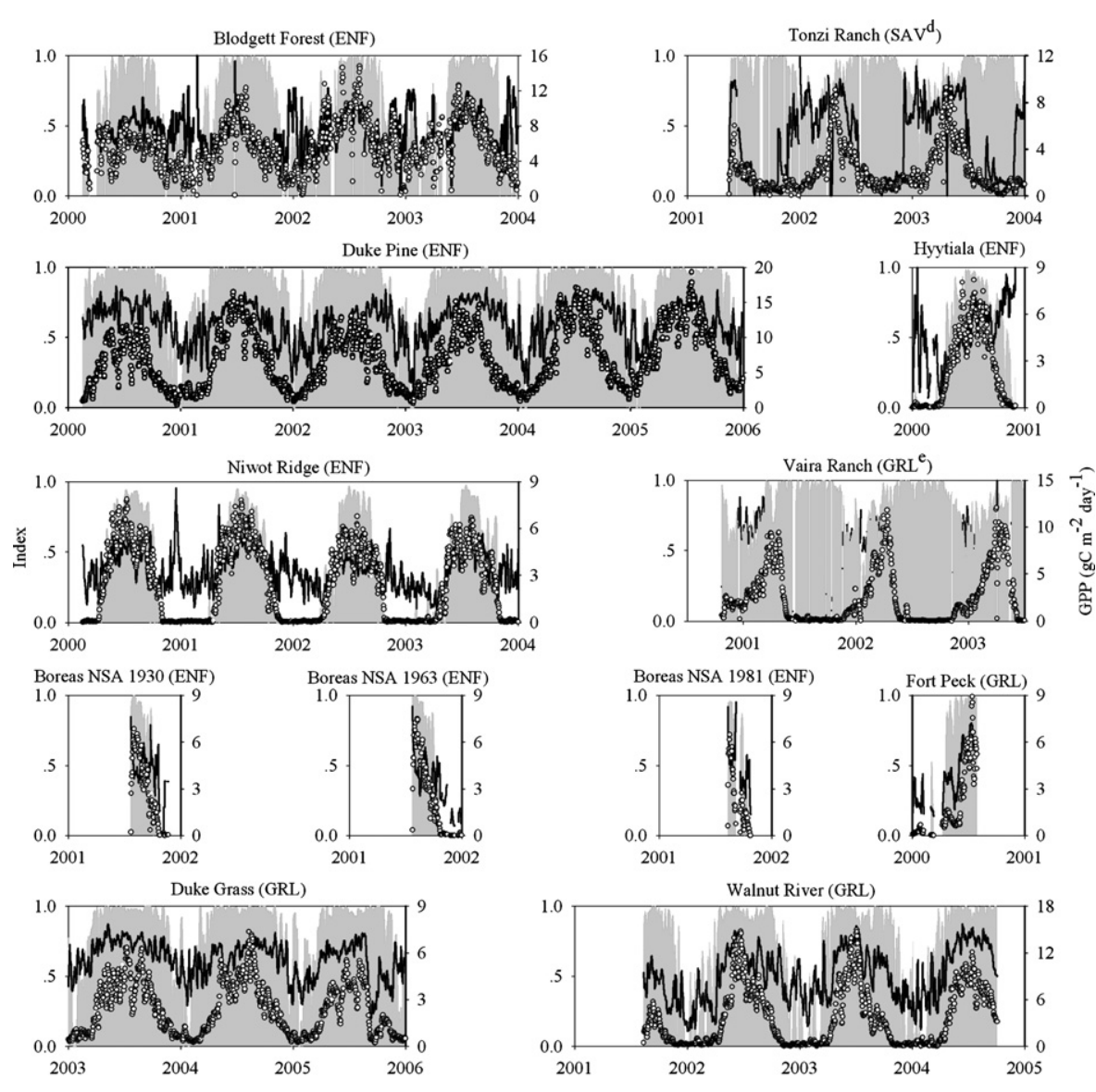

Year

Fig. 7. Daily dynamics of temperature and moisture indices with estimated GPP. The gray shadows represent temperature index. The black solid lines represent moisture index. The black filled dots represent GPP. ${ }^{\mathrm{d}}$ Savanna; ${ }^{\mathrm{e}} \mathrm{Grassland}$.

previous works (Williams et al., 1998; Rayment and Jarvis, 1999; Oechel et al., 2000; Saigusa et al., 2002; Turner et al., 2003). For example, Turner et al. (2003) found that the relationship was nonlinear in forest ecosystems because of the saturation of photosynthesis with increasing photosynthetic photon flux density
(PPFD). In this study, moisture and thermal factors were considered as the factors affecting LUE. A number of studies have suggested that water balance should be a major factor in determining terrestrial production and its spatial pattern. A close relationship between plant productivity and evapotranspiration was previously

Table 5

Comparison of fPAR based on measured LAI and fPAR of this study

\begin{tabular}{llllll}
\hline Site & LAI & fPAR $^{\mathrm{a}}$ & Measured time & fPAR & Reference \\
\hline Sarrebourg & 4.9 & 0.87 & Growing season of 1996-1997 & $0.89^{\mathrm{b}}$ & Granier et al. (2000) \\
Morgan Monroe & 4.9 & 0.87 & Background value & $0.86^{\mathrm{b}}$ & Curtis et al. (2002) \\
Metolius Young & 2.0 & 0.6 & July 1999 & $0.58^{\mathrm{b}}$ & Law et al. (2001) \\
Metolius & 4.3 & 0.83 & July 1999 & $0.75^{\mathrm{b}}$ & Law et al. (2001) \\
Vaira Ranch & 1.0 & 0.37 & DOY 25-40, 2002 & $0.54^{\mathrm{c}}$ & Xu and Baldocchi (2004) \\
& 1.8 & 0.56 & DOY 71-80, 2002 & $0.63^{\mathrm{c}}$ &
\end{tabular}

\footnotetext{
${ }^{\text {a }}$ Calculated fPAR values from Beer-Lambert law based on measured LAI.

b The average values of fPAR over growing season at this study.

${ }^{c}$ The values at same time with measured time.
} 
shown by Rosenzweig (1968), and mean annual precipitation was used to estimate NPP of those ecosystems that are not limited by low temperature (Lieth, 1975). Plant-available water appears to be the dominant control on leaf area index and NPP of the forests in the northwestern United States (Gholz, 1982). Stephenson (1990) and Neilson et al. (1992) illustrated the high correlation between the distribution of North American plant formations and water-balance parameters. In our study, we used evaporative fraction (EF) to evaluate moisture availability to plants. At most sites, water availability was the controlling factor of LUE for the entire growing season except at the beginning and the end when temperature was controlling in some ecosystems (Figs. 6 and 7), a result consistent with a number of phenological studies. In boreal ecosystems, there was a very good relationship between accumulated temperature summed above a given threshold and the timing of bud break (Hannerz, 1999; Linkosalo, 2000). Some authors have also stressed the role of soil temperature as the prime factor determining the timing of the onset of boreal, deciduous forests and temperate conifer photosynthesis (Schwarz et al., 1997; Jarvis and Linder, 2000; Baldocchi et al., 2005). Chen et al. (2005) found that the spatial patterns of beginning and end dates of growing season correlated significantly with the spatial patterns of mean air temperatures in spring and autumn, respectively, in temperate eastern China, and temperature during the growing season usually did not reach the level that incurred strong negative temperature effects on photosynthesis. In our study, temperature index had little impact on GPP during the growing season, in agreement with field observations (Polley et al., 1992; Bassow and Bazzaz, 1998).

We found that under the Mediterranean climate (e.g., Tonzi Ranch and Vaira Ranch), soil moisture was the dominant control factor during the growing season and temperature only occasionally limited the LUE after germination in the winter. These results were consistent with field phenological observations at Tonzi Ranch and Vaira Ranch that closely followed soil moisture fluctuations (Xu and Baldocchi, 2004). These authors found that grass seed germination normally occurs in the autumn, 1 week after a major rain event with total precipitation of at least $15 \mathrm{~mm}$. After germination, due to low soil and air temperature and occasional frosts, the grasses undergo a period of slow vegetative growth in the wintertime.

\subsection{Realized light use efficiency (LUE)}

Light use efficiency was the primary controlling factor in the LUE model for predicting GPP. Large discrepancies have arisen in previous studies because realized LUE has been determined using inconsistent methods due to different research objectives. LUE has represented the total NPP or aboveground NPP in most studies, but rarely to GPP (Gower et al., 1999). Whichever method is used, LUE is calculated as:

$$
\text { LUE }=\frac{P}{\text { APAR }}
$$

where $P$ may be NPP, aboveground NPP or GPP. If either NPP or aboveground NPP is chosen, there would be several effects on LUE variability. First, some photosynthates are immediately used for maintenance and growth respiration, and respiration has a different dependence on temperature and factors other than LUE (Gower et al., 1999). Hunt (1994) found that published LUE values ranged from 0.2 to $1.5 \mathrm{~g} \mathrm{C} \mathrm{MJ}^{-1}$ for woody vegetation, and hypothesized that this was the result of respiration from the $6 \%$ to $27 \%$ of living cells in the sapwood of woody stems. Second, the exclusion of important components of production (e.g., understory, ground cover, and fine roots) was an important source of error in most LUE estimates (Gower et al., 1999). Most LUE estimates were based on aboveground components of the overstory layer because few measurements of belowground primary production are available. Biomass allocation to belowground ranges from $20 \%$ to $75 \%$ of NPP in terrestrial biomes and therefore cannot be ignored. Many researchers calculate total NPP from measured aboveground primary production. However, the task of estimating the allocation fraction between aboveground and belowground primary production is complicated because of the limited understanding of the physiological controls on allocation constraints (Friedlingstein et al., 1999). The fraction of total NPP allocated to root production differs among plant functional groups, different environmental conditions, and with forest age (Law et al., 2001). Eddy covariance flux towers offer the best opportunity for estimating GPP at the ecosystem scale, and improving the calculation of LUE from GPP and APAR. In this study, GPP estimates from EC measurements were used to calculate realized LUE based on Eqs. (1) and (12).

Our study indicated that the mean daily realized LUE during the growing season was lowest at the boreal forest sites, highest at the deciduous broadleaf forests, and intermediate at the grasslands and mixed forests. This pattern was consistent with other studies (e.g., Turner et al., 2003; Gower et al., 1999). The LUE of deciduous forest ecosystems was highest because of ample thermal resources and moisture. For example, average air temperature and annual precipitation from 1999 to 
2003 were $12.42^{\circ} \mathrm{C}$ and $1030.5 \mathrm{~mm}$ at Morgan Monroe, respectively (http://www.modis.ornl.gov/modis/index. $\mathrm{cfm})$. The LUE values, $0.62 \mathrm{~g} \mathrm{C} \mathrm{m}^{-2} \mathrm{MJ}^{-1}$ APAR for Metolius Mid, $0.68 \mathrm{~g} \mathrm{C} \mathrm{m}^{-2} \mathrm{MJ}^{-1}$ APAR for Metolius Young and $0.86 \mathrm{~g} \mathrm{C} \mathrm{m}^{-2} \mathrm{MJ}^{-1}$ APAR for Metolius-old, were lower than the realized LUE at other sites because most of the precipitation in the region occurred between October and June, with the summer months lacking effective precipitation (normally $0 \pm 20 \mathrm{~mm}$ July through August) (Law et al., 2001). The values of EF were lower during the growing season than in the wintertime at these sites (Figs. 6 and 7), consistent with the precipitation pattern. In general, grasslands are sensitive to soil drought (Nouvellon et al., 2000), but in this study, the LUE value at Walnut River was $1.38 \mathrm{~g} \mathrm{C} \mathrm{m}^{-2} \mathrm{MJ}^{-1}$ APAR, second only to the LUE values of deciduous forest ecosystems. The higher LUE value at Walnut River was probably related to the presence of $\mathrm{C}_{4}$ plants (http://www.modis.ornl.gov/ modis/index.cfm) that can maintain a given rate of photosynthesis with less water and nitrogen compared to $\mathrm{C}_{3}$ plants (Chapin et al., 2002).

\section{Summary}

The light use efficiency (LUE) daily GPP model developed in this study, with a biome-independent invariant potential LUE, relies on only four driving variables: PAR, NDVI, air temperature, and evaporative fraction. Model calibration and validation at 28 FLUXNET sites in North America and Europe suggested that the model was robust and reliable across biomes and geographic regions. Comparison with MODIS-GPP suggested that the EC-LUE model offered better GPP predictions. The model can be a good candidate for mapping GPP at the regional to global scales because it is independent of land cover types, and all driving variables can be retrieved from satellites or standard weather observation networks. The suitability of the EC-LUE model for crop systems should be investigated in the future. In addition, the causes of large errors at several FLUXNET sites should be analyzed especially with regard to the quality of the input data such as NDVI.

\section{Acknowledgments}

This paper benefited from comments from Eugene Fosnight, John Hutchison, Bruce Wylie and several anonymous reviewers. We gratefully acknowledge the financial support from U.S. Geological Survey (the Geographic Analysis and Monitoring Program and the
Earth Surface Dynamics Program) and NASA Earth Science Enterprise (grant LUCC99-0022-0035). Liu's work was partially performed under U.S. Geological Survey contract 03CRCN0001. This work was also jointly supported by NKBRSF (No. G2006CB400502), National Natural Science Foundation of China (No. 40231018), and the Chinese Academy of Sciences (Nos. KSCX2- SW-133) and by the Office of Science (BER), U.S. Department of Energy.

\section{References}

Aber, J.D., Reich, P.B., Goulden, M.L., 1996. Extrapolating leaf $\mathrm{CO}_{2}$ exchange to the canopy: a generalized model of forest photosynthesis compared with measurements by eddy correlation. Oecologia 106, 257-265.

AmeriFlux, 2001. http://public.ornl.gov/ameriflux/Participants/Sites/ Map/index.cfm.

Baldocchi, D.D., 2003. Assessing the eddy covariance technique for evaluating carbon dioxide exchange rates of ecosystems: past, present and future. Global Change Biol. 9, 479-492.

Baldocchi, D.D., Black, T.A., Curtis, P.S., Falge, E., Fuentes, J.D., Granier, A., Gu, L., Knohl, A., Pilegaard, K., Schmid, H.P., Valentini, R., Wilson, K., Wofsy, S., Xu, L., Yamamoto, S., 2005. Predicting the onset of net carbon uptake by deciduous forests with soil temperature and climate data: a synthesis of FLUXNET data. Int. J. Biometeorol. 49 (6), 377-387.

Baldocchi, D.D., Xu, L.K., Kiang, N., 2004. How plant functionaltype, weather, seasonal drought, and soil physical properties alter water and energy fluxes of an oak-grass savanna and an annual grassland. Agric. For. Meteorol. 123 (1/2), 13-39.

Bassow, S.L., Bazzaz, F.A., 1998. How environmental conditions affect canopy leaf-level photosynthesis in four deciduous tree species. Ecology 79, 2660-2675.

Bolstad, P.V., Davis, K.J., Martin, J., Cook, B.D., Wang, W., 2004. Component and whole-system respiration fluxes in northern deciduous forests. Tree Physiol. 24 (5), 493-504.

Bondeau, A., Kicklighter, D.W., Kaduk, J., The Participants of the Potsdam NPP Model Intercomparison, 1999. Comparing global models of terrestrial net primary productivity (NPP): importance of vegetation structure on seasonal NPP estimates. Global Change Biol. 5, 35-45.

Braswell, B.H., Sacks, W.J., Linder, E., Schimel, D.S., 2005. Estimating diurnal to annual ecosystem parameters by synthesis of a carbon flux model with eddy covariance net ecosystem exchange observations. Global Change Biol. 11, 335-355.

Canadell, J.G., Mooney, H.A., Baldocchi, D.D., Berry, J.A., Ehleringer, B., Field, C.B., Gower, S.T., Hollinger, D.Y., Hunt, J.E., Jackson, R.B., Running, S.W., Shaver, G.R., Steffen, W., Trumbore, S.E., Valentini, R., Bond, B.Y., 2000. Carbon metabolism of the terrestrial biosphere: a multi-technique approach for improved understanding. Ecosystems 3, 115-130.

Chapin, M.C., Matson, P.A., Mooney, H.A. (Eds.), 2002. Principles of Terrestrial Ecosystem Ecology. Springer-Verlag, New York, Berlin, Heidelberg, p. 102.

Chen, X.Q., Hu, B., Yu, R., 2005. Spatial and temporal variation of phonological growing season and climate change impacts in temperature eastern China. Global Change Biol. 11, 1118-1130.

Coops, N.C., Waring, R.H., Law, B.E., 2005. Assessing the past and future distribution and productivity of ponderosa pine in the 
pacific northwest using a process model, 3-PG. Ecol. Model. 183, $107-124$.

Curtis, P.S., Hanson, P.J., Bolstad, P., Barford, C., Randolph, J.C., Schmid, H.P., Wilson, K.B., 2002. Biometric and eddy-covariance based estimates of annual carbon storage in five eastern North American deciduous forests. Agric. For. Meteorol. 113, 3-19.

Curtis, P.S., Vogel, C.S., Gough, C.M., Schmid, H.P., Su, H.B., Bovard, B.D., 2005. Respiratory carbon losses and the carbonuse efficiency of a northern hardwood forest, 1999-2003. New Phytol. 167, 437-456.

Davis, K.J., Bakwin, P.S., Yi, C.X., Berger, B.W., Zhao, C., Teclaw, R.M., Isebrands, J.G., 2003. The annual cycles of $\mathrm{CO}_{2}$ and $\mathrm{H}_{2} \mathrm{O}$ exchange over a northern mixed forest as observed from a very tall tower. Global Change Biol. 9, 1278-1293.

Desai, A.R., Bolstad, P.V., Cook, B.D., Davis, K.J., Carey, E.V., 2005. Comparing net ecosystem exchange of carbon dioxide between an old-growth and mature forest in the upper Midwest, USA. Agric. For. Meteorol. 128, 33-55.

Dufrene, E., Davi, H., Francois, C., Le Maire, G., Le Dantec, V., Granier, A., 2005. Modelling carbon and water cycles in a beech forest. Part I. Model description and uncertainty analysis on modelled NEE. Ecol. Model. 85, 407-436.

Falge, E., Baldocchi, D., Tenhunen, J., Aubinet, M., Bakwin, P., Berbigier, P., Bernhofer, C., Burba, G., Clement, R., Davis, K.J., Elbers, J.A., Goldstein, A.H., Grelle, A., Granier, A., Guomundsson, J., Hollinger, D., Kowalski, A.S., Katul, G., Law, B.E., Malhi, Y., Meyers, T., Monson, R.K., 2002. Seasonality of ecosystem respiration and gross primary production as derived from FLUXNET measurements. Agric. For. Meteorol. 113, 5374.

Friedlingstein, P., Joel, G., Field, C.B., Fung, I.Y., 1999. Toward an allocation scheme for global terrestrial carbon models. Global Change Biol. 5, 755-770.

Gholz, H.L., Clark, K.L., 2002. Energy exchange across a chronosequence of slash pine forests in Florida. Agric. For. Meteorol. 112 (2), 87-102.

Gholz, H.Z., 1982. Environmental limits on aboveground net primary production, leaf area and biomass in vegetation zones in the Pacific Northwest. Ecology 63, 469-481.

Gilmanov, T.G., Tieszen, L.L., Wylie, B.K., Flanagan, L., Frank, A., Meyers, T., 2005. Integration of $\mathrm{CO}_{2}$ flux and remotely-sensed data for primary production and ecosystem respiration analyses in the Northern Great Plains: potential for quantitative spatial extrapolation. Global Ecol. Biogeogr. 14, 271-292.

Goldstein, A.H., Hultman, N.E., Fracheboud, J.M., Bauer, M.R., Panek, J.A., Xu, M., Qi, Y., Guenther, A.B., Baugh, W., 2000. Effects of climate variability on the carbon dioxide, water, and sensible heat fluxes above a ponderosa pine plantation in the Sierra Nevada (CA). Agric. For. Meteorol. 101, 113-129.

Goulden, M.L., Wofsy, S.C., Harden, J.W., Trumbore, S.E., Crill, P.M., Gower, S.T., Fries, T., Daube, B.C., Fan, S.M., Sutton, D.J., Bazzaz, A., Munger, J.W., 1998. Sensitivity of boreal forest carbon balance to soil thaw. Science 279 (5348), 214-217.

Goulden, M.L., Winston, G.C., McMillan, A.M.S., Litvak, E.E., Read, E.L., Rocha, A.V., Elliot, J.R., 2006. An eddy covariance mesonet to measure the effect of forest age on land-atmosphere exchange. Global Change Biol. 12 (11), 2146-2162.

Gower, S.T., Kucharik, C.J., Norman, J.M., 1999. Direct and indirect estimation of leaf area index, fAPAR, and net primary production of terrestrial ecosystems. Remote Sens. Environ. 70, 29-51.

Granier, A., Ceschia, C., Damesin, C., Dufrene, E., Epron, D., Gross, P., Lebaube, S., Dantec, V.L.E., Goff, N.L.E., Lemoine, D., Lucot,
E., Ottorini, J.M., Pontailler, J.Y., Saugier, S., 2000. The carbon balance of a young Beech forest. Funct. Ecol. 14, 312-325.

Hannerz, M., 1999. Evaluation of temperature models for predicting bud burst in Norway spruce. Can. J. For. Res. 29, 1-11.

Heinsch, F.A., Zhao, M., Running, S.W., Kimball, J.S., Nemani, R.R., Davis, K.J., Bolstad, P.V., Cook, B.D., Desai, A.R., Ricciuto, D.M., Law, B.E., Oechel, W.C., Kwon, H., Luo, H., Wofsy, S.C., Dunn, A.L., Munger, J.W., Baldocchi, D.D., Xu, L., Hollinger, D.Y., Richardson, A.D., Stoy, P.C., Siqueira, M.B.S., Monson, R.K., Burns, S.P., Flanagan, L.B., 2006. Evaluation of remote sensing based terrestrial production from MODIS using AmeriFlux eddy tower flux network observations. IEEE Trans. Geosci. Remote Sens. 44, 1908-1925.

Hollinger, D.Y., Aber, J., Dail, B., Davidson, E.A., Goltz, S.M., Hughes, H., Leclerc, M.Y., Lee, J.T., Richardson, A.D., Rodrigues, C., Scott, N.A., Achuatavarier, D., Walsh, J., 2004. Spatial and temporal variability in forest-atmosphere $\mathrm{CO}_{2}$ exchange. Global Change Biol. 10, 1689-1706.

Hollinger, D.Y., Goltz, S.M., Davidson, E.A., Lee, J.T., Tu, K., Valentine, H.T., 1999. Seasonal patterns and environmental control of carbon dioxide and water vapour exchange in an ecotonal boreal forest. Global Change Biol. 5, 891-902.

Hunt, E.R., 1994. Relationship between woody biomass and PAR conversion efficiency for estimating net primary production from NDVI. Int. J. Remote Sens. 15, 1725-1730.

Jarvis, P., Linder, S., 2000. Constraints to growth of boreal forests. Nature 405, 904-905.

Kanji, G.K., 1999. 100 Statistical Tests. SAGE Publications, London. Kramer, K., Leinonen, I., Bartelink, H.H., Berbigier, P., Borghetti, M., Bernhofer, C., Cienciala, E., Dolman, A.J., Froer, O., Gracia, C.A., Granier, A., Grünwald, T., Hari, P., Jans, W., Kellomäki, S., Loustau, D., Magnani, F., Markkanen, T., Matteucci, G., Mohren, G.M.J., Moors, E., Nissinen, A., Peltola, H., Sabaté, S., Sanchez, A., Sontag, M., Valentini, R., Vesala, T., 2002. Evaluation of six process-based forest growth models using eddy-covariance measurements of $\mathrm{CO}_{2}$ and $\mathrm{H}_{2} \mathrm{O}$ fluxes at six forest sites in Europe. Global Change Biol. 8, 213-230.

Kurc, S.A., Small, E.E., 2004. Dynamics of evapotranspiration in semiarid grassland and shrubland ecosystems during the summer monsoon season, central New Mexico. Water Resour. Res. 40, W09305, doi:10.1029/2004WR003068.

Landsberg, J.J., 1986. Physiological Ecology of Forest Production. Academic Press, London, pp. 165-178.

Landsberg, J.J., Waring, R.H., 1997. A generalised model of forest productivity using simplified concepts of radiation-use efficiency, carbon balance and partitioning. For. Ecol. Manage. 95, 209-228.

Law, B.E., Thornton, P.E., Irvine, J., Anthoni, P.M., Tuy, S.V., 2001. Carbon storage and fluxes in ponderosa pine forests at different developmental stages. Global Change Biol. 7, 755-777.

Law, B.E., Turner, D., Campbell, J., Sun, O.J., Van Tuyl, S., Ritts, W.D., Cohen, W.B., 2004. Disturbance and climate effects on carbon stocks and fluxes across Western Oregon USA. Global Change Biol. 10, 1429-1444.

Law, B.E., Waring, R.H., 1994a. Combining remote sensing and climatic data to estimate net primary production across Oregon. Ecol. Appl. 4, 717-728.

Law, B.E., Waring, R.H., 1994b. Remote sensing of leaf area index and radiation intercepted by understory vegetation. Ecol. Appl. 4, 272-279.

Law, B.E., Williams, M., Anthoni, P.M., Baldocchi, D.D., Unsworth, M.H., 2000a. Measuring and modelling seasonal variation of carbon dioxide and water vapour exchange of a Pinus ponderosa 
forest subject to soil water deficit. Global Change Biol. 6, 613630.

Law, B.E., Waring, R.H., Anthoni, P.M., Aber, J.D., 2000b. Measurements of gross and net ecosystem productivity and water vapour exchange of a Pinus ponderosa ecosystem, and an evaluation of two generalized models. Global Change Biol. 6 (2), 155-168.

Lewis, J.M., 1995. The story behind the Bowen ratio. Bull. Am. Meteorol. Soc. 76, 2433-2443.

Lieth, H., 1975. Modeling the primary productivity of the world. In: Lieth, H., Whittaker, R.H. (Eds.), Primary Productivity of the Biosphere. Springer-Verlag, New York, pp. 237-262.

Linkosalo, T., 2000. Mutual regularity of spring phenology of some boreal tree species: predicting with other species and phonological models. Can. J. For. Res. 30, 667-673.

Marshall, B., Biscoe, P.V., 1980. A model of $C_{3}$ leaves describing the dependence of net photosynthesis on irradiance. J. Exp. Bot. 31, 29-39.

Monson, R.K., Turnipseed, A.A., Sparks, J.P., Harley, P.C., ScottDenton, L.E., Sparks, K., Huxman, T.E., 2002. Carbon sequestration in a high-elevation, subalpine forest. Global Change Biol. 8, 459-478.

Myneni, R.B., Williams, D.L., 1994. On the relationship between FAPAR and NDVI. Remote Sens. Environ. 49, 200-221.

Neilson, R.P., King, C.A., Koerper, E., 1992. Toward a rule-based biome model. Landscape Ecol. 7, 27-43.

Nouvellon, Y., Seen, D.L., Verma, S.G., 2000. Time course of radiation use efficiency in a shortgrass ecosystem: consequences for remotely sensed estimation of primary production. Remote Sens. Environ. 71, 43-55.

Novick, K.A., Stoy, P.C., Katul, G.G., Ellsworth, D.E., Siqueira, M.B.S., Juang, J., Oren, R., 2004. Carbon dioxide and water vapor exchange in a warm temperate grassland. Oecologia 138, 259-274.

Oechel, W.C., Vourlitis, G.L., Verfailier, J., Crawford, T., Brooks, S., Dumas, E., Hope, A., Stow, D., Boynton, B., Nosov, V., Zulueta, R., 2000. A scaling approach for quantifying the net $\mathrm{CO}_{2}$ flux of the Kuparuk river basin, Alaska. Global Change Biol. 6, 160-173.

Pataki, D.E., Oren, R., 2003. Species differences in stomatal control of water loss at the canopy scale in a mature bottomland deciduous forest. Adv. Water Resour. 26, 1267-1278.

Polley, H.W., Norman, J.M., Arkebauer, T.J., Walter-Shea, E.A., Greegor, D.H., Bramer, B., 1992. Leaf gas exchange of Andropogon gerardii Vitman, Panicum virgatum L. and Sorghastrum mutans (L.) Nash in a tallgrass prairie. J. Geophys. Res. 97, 18837-18844.

Potter, C.B., Randerson, J.T., Field, C.B., Matson, P.A., Vitousek, P.M., Mooney, H.A., Klooster, S.A., 1993. Terrestrial ecosystem production: a process model based on global satellite and surface data. Global Biogeochem. Cycle 7, 811-841.

Prince, S.D., Goward, S.N., 1995. Global primary production: a remote sensing approach. J. Biogeogr. 22, 815-835.

Raich, J.W., Rastetter, E.B., Melillo, J.M., Kicklighter, D.W., Steudler, P.A., Peterson, B.J., Grace, A.L., Moore, B., Vorosmarty, C.J., 1991. Potential net primary productivity in South America: application of a global model. Ecol. Appl. 1, 399-429.

Rayment, M.B., Jarvis, P.G., 1999. Seasonal gas exchange of black spruce using an automatic branch bag system. Can. J. For. Res. 29, $1528-1538$.

Rosenzweig, M.L., 1968. Net primary productivity of terrestrial communities: prediction from climatological data. Am. Nat. $102,67-74$.

Ruimy, A., Kergoat, L., Bondeau, A., The Participants of the Potsdam NPP Model Intercomparison, 1999. Comparing global models of terrestrial net primary productivity (NPP): analysis of differences in light absorption and light-use efficiency. Global Change Biol. 5, $56-64$.

Ruimy, A., Saugier, B., 1994. Methodology for the estimation of terrestrial net primary production from remotely sensed data. J. Geophys. Res. 97, 18515-18521.

Running, S.W., Nemani, R., Glassy, J.M., Thornton, P.E., 1999. MODIS daily photosynthesis (PSN) and annual net primary production (NPP) product (MOD17), algorithm theoretical basis document, version 3.0. In: http://modis.gsfc.nasa.gov/.

Running, S.W., Nemani, R.R., Heinsch, F.A., Zhao, M.S., Reeves, M., Hashimoto, H., 2004. A continuous satellite-derived measure of global terrestrial primary production. Bioscience 54, 547-560.

Running, S.W., Thornton, P.E., Nemani, R., Glassy, J.M., 2000. Global terrestrial gross and net primary productivity from the earth observing system. In: Sala, O.E., Jackson, R.B., Mooney, H.A. (Eds.), Methods in Ecosystem Science. Springer-Verlag, New York, pp. 44-57.

Russell, G., Jarvis, P.G., Monteith, J.L., 1989. Absorption of radiation by canopies and stand growth. In: Russell, G., Marshall, B., Jarvis, P.G. (Eds.), Plant Canopies: Their Growth, Form and Function. Cambridge Univ. Press, Cambridge, pp. 21-39.

Saigusa, N., Yamamotoa, S., Murayamaa, S., Kondoa, H., Nishimurab, N., 2002. Gross primary production and net ecosystem exchange of a cool-temperate deciduous forest estimated by the eddy covariance method. Agric. For. Meteorol. 112, 203-215.

Saito, M., Miyata, A., Nagai, H., Yamada, T., 2005. Seasonal variation of carbon dioxide exchange in rice paddy field in Japan Tomoyasu Yamada. Agric. For. Meteorol. 135, 93-109.

Schmid, H.P., Grimmond, C.S.B., Cropley, F., Offerle, B., Su, H.B., 2000. Measurements of $\mathrm{CO}_{2}$ and energy fluxes over a mixed hardwood forest in the mid-western United States. Agric. For Meteorol. 103 (4), 357-374.

Schwarz, P.A., Fahey, T.J., Dawson, T.E., 1997. Seasonal air and soil temperature effects on photosynthesis in red spruce (Picea rubens) saplings. Tree Physiol. 17, 187-194.

Sims, D.A., Rahman, A.F., Cordova, V.D., Baldocchi, D.D., Flanagan, L.B., Goldstein, A.H., Hollinger, D.Y., Misson, L., Monson, R.K., Schmid, H.P., Wofsy, S.C., Xu, L.K., 2005. Midday values of gross $\mathrm{CO}_{2}$ flux and light use efficiency during satellite overpasses can be used to directly estimate eight-day mean flux. Agric. For. Meteorol. 131, 1-12.

Song, J., Liao, K., Coulter, R.L., Lesht, B.M., 2005. Climatology of the low-level jet at the southern Great Plains atmospheric Boundary Layer Experiments site. J. Appl. Meteorol. 44, 1593-1606.

Stephenson, N.L., 1990. Climate control of vegetation distribution: the role of the water balance. Am. Nat. 135, 649-670.

Stoy, P.C., Katul, G.G., Siqueira, M.B.S., Juang, J.Y., Novick, K.A., Oren, R., 2006. An evaluation of methods for partitioning eddy covariance-measured net ecosystem exchange into photosynthesis and respiration. Agric. For. Meteorol. 141, 2-18.

Suleiman, A., Crago, R., 2004. Hourly and daytime evapotranspiration from grassland using radiometric surface temperatures. Agron. J. 96, 384-390.

Turner, D.P., Urbanski, S., Bremer, D., Wofsy, S.C., Meyers, T., Gower, S.T., Gregory, M., 2003. A cross-biome comparison of daily light-use efficiency for gross primary production. Global Change Biol. 9, 385-395.

Valentini, R. (Ed.), 2003. Fluxes of Carbon, Water and Energy of European Forests, Springer Verlag, Heidelberg, pp. 260.

van Wijk, M.T., Bouten, W.M.T., 2002. Simulating daily and halfhourly fluxes of forest carbon dioxide and water vapor exchange with a simple model of light and water use. Ecosystems 5, 597-610. 
Venturini, V., Bisht, G., Islam, S., Jiang, L., 2004. Comparison of evaporative fractions estimated from AVHRR and MODIS sensors over South Florida. Remote Sens. Environ. 93, 77-86.

Veroustraete, F., Sabbe, H., Eerens, H., 2002. Estimation of carbon mass fluxes over Europe using the C-Fix model and Euroflux data. Remote Sens. Environ. 83, 376-399.

Wang, Q., Tenhunen, J., Falge, E., Bernhofer, C.H., Granier, A., Vesala, T., 2003. Simulation and scaling of temporal variation in gross primary production for coniferous and deciduous temperate forests. Global Change Biol. 10, 37-51.

Waring, R.H., Landsberg, J.J., Williams, M., 1998. Net primary production of forests: a constant fraction of gross primary production? Tree Physiol. 18, 129-134.

Williams, M., Malhi, Y., Nobre, D., Rastetter, E.B., Grace, J., Pereira, M.G.P., 1998. Seasonal variation in net carbon exchange and evapotranspiration in a Brazilian rain forest: a modeling analysis. Plant Cell Environ. 21, 935-968.

Williams, M., Schwarz, P.A., Law, B., Irvine, J., Kurpius, M.R., 2005. An improved analysis of forest carbon dynamics using data assimilation. Global Change Biol. 11, 89-105.
Xiao, X.M., Zhang, Q.Y., Braswell, B., Urbanski, S., Boles, S., Wofsy, S., Moore, B., Ojima, D., 2004. Modeling gross primary production of temperate deciduous broadleaf forest using satellite images and climate data. Remote Sens. Environ. 91, 256-270.

Xiao, X.M., Zhang, Q.Y., Hollinger, D., Aber, J., Moore, B., 2005a. Modeling gross primary production of an evergreen needleleaf forest using MODIS and climate data. Ecol. Appl. 15 (3), 954969.

Xiao, X.M., Zhang, Q.Y., Saleska, S., Hutyra, L., Camargo, P., Wofsy, S., Frolking, S., Boles, S., Keller, M., Moore, B., 2005b. Satellite-based modeling of gross primary production in a seasonally moist tropical evergreen forest. Remote Sens. Environ. 94, 105-122.

Xu, L.K., Baldocchi, D.D., 2004. Seasonal variation in carbon dioxide exchange over a Mediterranean annual grassland in California. Agric. For. Meteorol. 123, 79-96.

Zhang, Y.Q., Liu, C.M., Yu, Q., Shen, Y.J., Kendy, E., Kondoh, A., Tang, C.Y., Sun, H.Y., 2004. Energy fluxes and the PriestleyTaylor parameter over winter wheat and maize in the North China Plain. Hydrol. Process. 18, 2235-2246. 